OPEN ACCESS

Edited by: Heather Shannon Smallwood, University of Tennessee Health Sciences Center, United States

Reviewed by:

Masmudur Mohammed Rahman, Arizona State University, United States Matthias Walter

University Hospital Basel, Switzerland

${ }^{*}$ Correspondence: Jitender Sharma jitendersharma.clinchem@gmail.com Vikas Sood v.sood@jamiahamdard.ac.in; vikas1101@gmail.com

Specialty section: This article was submitted to Virus and Host, a section of the journal Frontiers in Cellular and Infection Microbiology

Received: 01 March 2021 Accepted: 28 September 2021 Published: 25 October 2021

Citation:

Sharma J, Rajput R, Bhatia M. Arora P and Sood V (2021) Clinical Predictors of COVID-19 Severity and Mortality: A Perspective. Front. Cell. Infect. Microbiol. 11:674277. doi: 10.3389/fcimb.2021.674277

\section{Clinical Predictors of COVID-19 Severity and Mortality: A Perspective}

\author{
Jitender Sharma ${ }^{1 *}$, Roopali Rajput ${ }^{2}$, Manika Bhatia $^{3}$, Pooja Arora ${ }^{3}$ and Vikas Sood ${ }^{2 *}$ \\ ${ }^{1}$ Department of Biochemistry, All India Institute of Medical Sciences, Bathinda, India, ${ }^{2}$ Department of Biochemistry, School \\ of Chemical and Life Sciences, Jamia Hamdard, New Delhi, India, ${ }^{3}$ Department of Zoology, Hansraj College, University of \\ Delhi, Delhi, India
}

The COVID-19 pandemic has caused huge socio-economic losses and continues to threat humans worldwide. With more than 4.5 million deaths and more than 221 million confirmed COVID-19 cases, the impact on physical, mental, social and economic resources is immeasurable. During any novel disease outbreak, one of the primary requirements for effective mitigation is the knowledge of clinical manifestations of the disease. However, in absence of any unique identifying characteristics, diagnosis/ prognosis becomes difficult. It intensifies misperception and leads to delay in containment of disease spread. Numerous clinical research studies, systematic reviews and meta-analyses have generated considerable data on the same. However, identification of some of the distinct clinical signs and symptoms, disease progression biomarkers and the risk factors leading to adverse COVID-19 outcomes warrant in-depth understanding. In view of this, we assessed 20 systematic reviews and meta-analyses with an intent to understand some of the potential independent predictors/biomarkers/risk factors of COVID-19 severity and mortality.

Keywords: SARS-CoV-2, prognosis, biomarkers, risk factors, obesity, diabetes, radiological, sleep

\section{INTRODUCTION}

Coronaviruses belong to Coronaviridae family of viruses. The degree of disease caused by coronaviruses can vary from mild like common cold to severe like severe acute respiratory syndrome (SARS) and the middle east respiratory syndrome (MERS). These viruses have been successful in crossing inter-species barriers. SARS-coronavirus jumped from civet cats to humans while MERS-coronavirus got transmitted to humans from camels (Woo et al., 2012). The recent emergence of the novel SARS Coronavirus 2 (SARS-CoV-2) is another incidence of zoonotic transmission of coronaviruses. As per the genomic sequence analysis, the source of novel SARSCoV-2 is speculated to be a previously identified bat coronavirus strain RaTG13 (96.2- 97.41\% identity match) (Shi, 2021; Malaiyan et al., 2021) or pangolin-CoV (91.02- 92.22\% genomic identity match) (Zhang T. et al., 2020; Malaiyan et al., 2021). However, the origin of the SARS-CoV-2 is still unclear due to the lack of definitive evidence. Further investigations are being undertaken in this regard (WHO News release, 2021).

Since the first case reported late in 2019, SARS-CoV-2 has taken more than 4.5 million human lives (as of September 08, 2021) and continues to spread worldwide with more than 221 million 
confirmed cases (WHO, 2021). The case fatality rate of the disease caused by the SARS-CoV-2 (3.26- $4.16 \%$ in Latin America; 5.8\% in the United States) (Undurraga et al., 2021; Loomba et al., 2021) is way less as compared to the previous coronavirus outbreaks (Zhu et al., 2020). Nevertheless, the fatality caused by Coronavirus Disease 2019 (COVID-19) has surpassed that of the SARS and MERS combined (Song et al., 2019). The COVID-19 pandemic has also resulted in huge economic losses (speculated to be trillions of dollars) around the world (Emem, 2020).

COVID-19 initially emerged as novel pneumonia of unknown etiology with majorly non-specific symptoms and quite quickly engulfed the entire globe. During the initial months of the pandemic, lack of specific diagnostic modalities, the variable intensity of the disease surveillance, changing case definitions, asymptomatic period of infection and overwhelmed health care facilities largely contributed to the rapid spread of the virus, resulting in the global outbreak. Also, the novel COVID-19 in a way bridged the gap between the developing and developed world, bringing all on the same footing. With more than 85 million confirmed cases, the Americas are the worst affected, followed by Europe ( $>66$ million), South-East Asia ( $>41$ million), the East Mediterranean region (> 15 million), Western Pacific (> 7 million) and Africa ( $>5$ million) (WHO, 2021). A major breakthrough in the current pandemic period witnessed rapid development and administration of different vaccines against COVID-19. However, despite the massive vaccine roll-out programs, the emergence of virus variants sustains the challenge of controlling the pandemic and continues to spread in its wild-type and mutant forms across the globe.

Since the onset of the disease, several groups have published various systematic reviews and meta-analyses that aim to shed light on the disease prognosis. However, the evidence was limited and the data were mostly heterogenous. Further, due to everchanging viral dynamics, multiple new symptoms have been witnessed. With the generation of more data, it is expected that the analysis will continue with a focus on identifying unique clinical manifestations, laboratory findings, radiological investigations, and therapy that could correlate with varying degree of COVID-19 or adverse outcomes, and fatality. However, the studies published earlier have highlighted the significance of some important biomarkers and clinical features in diagnosis, prognosis and management of mild to severe COVID-19.

\section{METHODOLOGY}

In the present work, we aim to identify key players of the disease and summarize important findings from already published studies on diverse clinical aspects of COVID-19. The search terms 'COVID-19', 'SARS-CoV-2', 'clinical predictors', 'signs and symptoms' were used individually or in appropriate combinations and only the 'systematic reviews and/or metaanalysis' articles that were published until February, 2021 were included for the present work. We carefully studied 20 systematic review/meta-analysis/meta-regression articles (Table 1A) that spanned the global population.

\section{PROGNOSTIC FACTORS ASSOCIATED WITH SEVERE COVID-19}

\section{Clinical Manifestations}

Since the start of the pandemic, COVID-19 displayed a wide spectrum of clinical signs and symptoms, which included: fever, cough, sore throat, nasal congestion, sputum, headache, diarrhea, fatigue, dyspnea, chest tightness, myalgia, nausea, rhinorrhea, dizziness or confusion, hemoptysis, anorexia, vomiting, chest and abdominal pain (Huang et al., 2020; Jutzeler et al., 2020; Mudatsir et al., 2020). The eagerness to know any unique/distinct features was evident even in the layman. Fever, cough, fatigue, dyspnea (Figliozzi et al., 2020; Israfil et al., 2021) and a loss of sense of taste and smell (Hannum et al., 2020) remained some of the most experienced and identifying symptoms. In a systematic review involving more than 12000 patients, fever was the most common clinical manifestation in adults (78.5\%), pregnant women $(71.4 \%)$, pediatric and neonatal $(53.1 \%)$ patients. Other important clinical signs and symptoms were cough $(53.8 \%)$ and fatigue $(25 \%)$ in adults, cough $(41.4 \%)$ and myalgia $(33.3 \%)$ in pregnant women and cough (47.9\%) and sputum $(27.5 \%)$ in children and neonates (Jutzeler et al., 2020). Only about 5\% of patients were asymptomatic. Another meta-analysis, involving early data from 3578 patients, identified relation of dyspnea [odds ratio $(\mathrm{OR})=3.28,95 \%$ confidence interval (CI) 2.09- 5.15], anorexia $(\mathrm{OR}=1.83,95 \% \mathrm{CI} 1.00-3.34)$, fatigue $(\mathrm{OR}=2.00,95 \%$ CI 1.25-3.20) and dizziness $(\mathrm{OR}=2.67,95 \% \mathrm{CI} 1.18-6.01)$ with COVID-19 severity (Mudatsir et al., 2020). The vastly experienced COVID-19 symptoms, viz., fever, cough and breathing problem have been associated with problems in having sound sleep (Ferrando et al., 2016; Singh et al., 2020). An interesting systematic review and meta-analysis attempted to understand the impact of COVID-19 pandemic on quality or quantity of sleep under different study groups: COVID-19 patients, healthcare workers and the general population (Jahrami et al., 2021). As expected, about $75 \%$ of the COVID-19 patients had disturbed sleep, which was the highest prevalence among the different study groups (Jahrami et al., 2021). Physical pain or side-effects of the treatments were also speculated to impact the sound sleep in COVID-19 patients (Shi et al., 2020). These findings suggest that monitoring of sleep problems must not be ignored during COVID-19.

\section{Comorbidities as Risk Factors for Adverse Outcomes of COVID-19}

In one of the early meta-analyses aimed at assessing the impact of comorbidities on the course and clinical outcome of COVID-19, it was found that about $31 \%$ of adult patients $(2329 / 7608)$ had comorbidities, with hypertension being the most prevalent condition $(20.93 \%, 1352 / 6460)$, followed by heart failure (10.5\%, 37/354), diabetes mellitus $(10.4 \%, 678 / 6535)$ and coronary heart disease $(8.5 \%, 194 / 2388)$ (Jutzeler et al., 2020). 
TABLE 1A | Overview of the methodology of the analyzed systematic reviews and meta-analysis in relation to severity, adverse prognosis and mortality of COVID-19.

\begin{tabular}{|c|c|c|c|c|c|c|c|c|c|c|c|c|}
\hline \multirow{2}{*}{$\begin{array}{l}\text { S. } \\
\text { No. }\end{array}$} & \multirow[t]{2}{*}{ Reference } & \multirow{2}{*}{$\begin{array}{c}\text { Date of } \\
\text { publication } \\
\text { (or acceptance } \\
\text { for publication) }\end{array}$} & \multicolumn{10}{|c|}{ Methodology } \\
\hline & & & $\begin{array}{l}\text { Type of } \\
\text { analysis }\end{array}$ & $\begin{array}{l}\text { Diseases } \\
\text { compared }\end{array}$ & Features analyzed & Data sources & Data set & $\begin{array}{l}\text { Records } \\
\text { screened }\end{array}$ & $\begin{array}{l}\text { Records } \\
\text { selected }\end{array}$ & $\begin{array}{l}\text { Period } \\
\text { (up to) }\end{array}$ & $\begin{array}{l}\text { Total patients } \\
\text { studied }\end{array}$ & Region of study \\
\hline 1. & $\begin{array}{l}\text { Zhang JJY. } \\
\text { et al., } 2020\end{array}$ & May 14,2020 & $\begin{array}{l}\text { Systematic } \\
\text { review, } \\
\text { meta- } \\
\text { analysis } \\
\text { and meta- } \\
\text { regression }\end{array}$ & COVID-19 & $\begin{array}{l}\text { Laboratory } \\
\text { investigations as } \\
\text { predictors of poor } \\
\text { COVID-19 outcomes; } \\
\text { and efficacy of therapies } \\
\text { (involving experimental } \\
\text { antiviral and } \\
\text { immunomodulatory } \\
\text { treatments) }\end{array}$ & $\begin{array}{l}\text { Ovid MEDLINE, EMBASE, } \\
\text { CENTRAL and PubMed }\end{array}$ & Heterogenous & 1481 & 45 & $\begin{array}{l}\text { March } \\
15 \\
2020\end{array}$ & 4203 & $\begin{array}{l}\text { China, Singapore, } \\
\text { South Korea and } \\
\text { Hong Kong }\end{array}$ \\
\hline 2. & $\begin{array}{l}\text { Li et al., } \\
2021\end{array}$ & June 12, 2020 & $\begin{array}{l}\text { Systematic } \\
\text { review and } \\
\text { meta- } \\
\text { analysis }\end{array}$ & COVID-19 & $\begin{array}{l}\text { Clinical features and } \\
\text { outcome of severe and } \\
\text { non -severe pneumonia } \\
\text { patients }\end{array}$ & PubMed, EMBASE, Cochrane & Heterogenous & 201 & 12 & $\begin{array}{l}\text { April } \\
14 \\
2020\end{array}$ & 2445 & China \\
\hline 3. & $\begin{array}{l}\text { Földi et al., } \\
2020\end{array}$ & June 21, 2020 & $\begin{array}{l}\text { Systematic } \\
\text { review, } \\
\text { meta- } \\
\text { analysis } \\
\text { and meta- } \\
\text { regression }\end{array}$ & COVID-19 & Obesity as a risk factor & $\begin{array}{l}\text { MEDLINE (via PubMed), } \\
\text { EMBASE, CENTRAL, Scopus } \\
\text { and Web of Science }\end{array}$ & Heterogenous & 15168 & 24 & $\begin{array}{l}\text { May } \\
11 \\
2020\end{array}$ & $\begin{array}{l}\text { Meta-analysis: } \\
2,770 \text { and } 509 \\
\text { for ICU } \\
\text { admission and } \\
\text { IMV } \\
\text { requirement, } \\
\text { respectively } \\
\text { Meta- } \\
\text { regression: } \\
2522\end{array}$ & $\begin{array}{l}\text { China, France, USA, } \\
\text { Portugal, Netherlands, } \\
\text { Italy and Qatar }\end{array}$ \\
\hline 4. & $\begin{array}{l}\text { Lu et al., } \\
2020\end{array}$ & July 04, 2020 & $\begin{array}{l}\text { Systematic } \\
\text { review and } \\
\text { meta- } \\
\text { analysis }\end{array}$ & $\begin{array}{l}\text { COVID-19, } \\
\text { SARS and } \\
\text { MERS }\end{array}$ & Predictors of mortality & $\begin{array}{l}\text { MEDLINE, Epistemonikos, } \\
\text { COCHRANE, CKNI, } \\
\text { WANFANG STATA and manual } \\
\text { search }\end{array}$ & Heterogenous & 712 & 28 & $\begin{array}{l}\text { April } \\
11 \\
2020\end{array}$ & $\begin{array}{l}\text { 16095 (COVID- } \\
\text { 19: } 11818 ; \\
\text { SARS: 3292; } \\
\text { MERS: 985) }\end{array}$ & $\begin{array}{l}\text { COVID-19: China, } \\
\text { Italy, South Korea and } \\
\text { the United States } \\
\text { SARS: Beijing, } \\
\text { Guangdong, Shanxi, } \\
\text { Hong Kong and } \\
\text { Taiwan in China, and } \\
\text { Toronto } \\
\text { MERS: Saudi Arabia } \\
\text { and South Korea }\end{array}$ \\
\hline 5. & $\begin{array}{l}\text { Figliozzi } \\
\text { et al., } 2020\end{array}$ & July 20, 2020 & $\begin{array}{l}\text { Systematic } \\
\text { review and } \\
\text { meta- } \\
\text { analysis }\end{array}$ & COVID-19 & $\begin{array}{l}\text { Predictors of adverse } \\
\text { prognosis }\end{array}$ & PubMed, MEDLINE, Scopus & Heterogenous & 6843 & 49 & $\begin{array}{l}\text { April } \\
24, \\
2020\end{array}$ & 20211 & $\begin{array}{l}\text { China, USA, France, } \\
\text { Japan, Italy and } \\
\text { Canada }\end{array}$ \\
\hline 6. & $\begin{array}{l}\text { Henry et al., } \\
2020\end{array}$ & July 20, 2020 & $\begin{array}{l}\text { Systematic } \\
\text { review and } \\
\text { meta- } \\
\text { analysis }\end{array}$ & COVID-19 & $\begin{array}{l}\text { Association of 'at } \\
\text { admission lymphopenia } \\
\text { and neutrophilia' with } \\
\text { COVID-19 severity and } \\
\text { mortality }\end{array}$ & PubMed, CNKI, CENTRAL & Heterogenous & 53 & 22 & $\begin{array}{l}\text { May } \\
06 \\
2020\end{array}$ & 4969 & China, USA and Italy \\
\hline
\end{tabular}




\begin{tabular}{|c|c|c|c|c|c|c|c|c|c|c|c|c|}
\hline \multirow{2}{*}{$\begin{array}{l}\text { S. } \\
\text { No. }\end{array}$} & \multirow[t]{2}{*}{ Reference } & \multirow{2}{*}{$\begin{array}{c}\text { Date of } \\
\text { publication } \\
\text { (or acceptance } \\
\text { for publication) }\end{array}$} & \multicolumn{10}{|c|}{ Methodology } \\
\hline & & & $\begin{array}{l}\text { Type of } \\
\text { analysis }\end{array}$ & $\begin{array}{l}\text { Diseases } \\
\text { compared }\end{array}$ & Features analyzed & Data sources & Data set & $\begin{array}{l}\text { Records } \\
\text { screened }\end{array}$ & $\begin{array}{l}\text { Records } \\
\text { selected }\end{array}$ & $\begin{array}{l}\text { Period } \\
\text { (up to) }\end{array}$ & $\begin{array}{l}\text { Total patients } \\
\text { studied }\end{array}$ & Region of study \\
\hline 7. & $\begin{array}{l}\text { Shao et al., } \\
2020\end{array}$ & July 22, 2020 & $\begin{array}{l}\text { Systematic } \\
\text { review and } \\
\text { meta- } \\
\text { analysis }\end{array}$ & COVID-19 & $\begin{array}{l}\text { Association of AKI with } \\
\text { severe COVID-19 and } \\
\text { related mortality }\end{array}$ & $\begin{array}{l}\text { PubMed, Web of Science, } \\
\text { Science Direct, medRxiv }\end{array}$ & Heterogenous & 878 & 40 & $\begin{array}{l}\text { June } \\
20 \\
2020\end{array}$ & 24527 & $\begin{array}{l}\text { China, South Korea, } \\
\text { Korea, Spain, New } \\
\text { York, Kuwait and } \\
\text { Turkey }\end{array}$ \\
\hline 8. & $\begin{array}{l}\text { Li et al., } \\
2020\end{array}$ & July 28, 2020 & $\begin{array}{l}\text { Systematic } \\
\text { review and } \\
\text { meta- } \\
\text { analysis }\end{array}$ & COVID-19 & $\begin{array}{l}\text { Association of cardiac } \\
\text { injury and severity and } \\
\text { mortality }\end{array}$ & $\begin{array}{l}\text { PubMed, EMBASE, Cochrane, } \\
\text { CNKI, medRxiv, ChinaXiv }\end{array}$ & Heterogenous & 1331 & 23 & $\begin{array}{l}\text { March } \\
30, \\
2020\end{array}$ & 4631 & China \\
\hline 9. & $\begin{array}{l}\text { Ghahramani } \\
\text { et al., } 2020\end{array}$ & $\begin{array}{l}\text { August 03, } \\
2020\end{array}$ & $\begin{array}{l}\text { Systematic } \\
\text { review and } \\
\text { meta- } \\
\text { analysis }\end{array}$ & COVID-19 & $\begin{array}{l}\text { Laboratory features of } \\
\text { severe and non-severe } \\
\text { patients }\end{array}$ & $\begin{array}{l}\text { PubMed, Web of Science, } \\
\text { Science, EMBASE, Scopus }\end{array}$ & Heterogenous & 1988 & 22 & $\begin{array}{l}\text { March } \\
03 \\
2020\end{array}$ & 3396 & China and Singapore \\
\hline 10. & $\begin{array}{l}\text { Jutzeler } \\
\text { et al., } 2020\end{array}$ & $\begin{array}{l}\text { August 04, } \\
2020\end{array}$ & $\begin{array}{l}\text { Systematic } \\
\text { review and } \\
\text { meta- } \\
\text { analysis }\end{array}$ & COVID-19 & $\begin{array}{l}\text { Risk ratio of } \\
\text { comorbidities, clinical } \\
\text { features, laboratory } \\
\text { parameters, imaging } \\
\text { features, treatment and } \\
\text { complications with } \\
\text { morbidity and mortality }\end{array}$ & $\begin{array}{l}\text { PubMed, Web of Science, } \\
\text { EMBASE, Scopus, manual } \\
\text { search }\end{array}$ & Heterogenous & 2605 & 148 & $\begin{array}{l}\text { March } \\
28 \\
2020\end{array}$ & 12149 & $\begin{array}{l}\text { China, Italy, USA, } \\
\text { South Korea, Taiwan, } \\
\text { Germany, France, } \\
\text { Scotland, Japan, } \\
\text { Vietnam, Canada, } \\
\text { Singapore, Belgium, } \\
\text { Finland, Russia, Spain } \\
\text { and Sweden }\end{array}$ \\
\hline 11. & $\begin{array}{l}\text { Lippi et al., } \\
2020\end{array}$ & $\begin{array}{l}\text { August 25, } \\
2020\end{array}$ & $\begin{array}{l}\text { Systematic } \\
\text { review and } \\
\text { meta- } \\
\text { analysis }\end{array}$ & COVID-19 & $\begin{array}{l}\text { RDW as predictor of } \\
\text { severity }\end{array}$ & $\begin{array}{l}\text { MEDLINE, Web of Science, } \\
\text { Science, Scopus }\end{array}$ & Heterogenous & 13 & 3 & $\begin{array}{l}\text { July, } \\
2020\end{array}$ & 11445 & China, USA \\
\hline 12. & $\begin{array}{l}\text { Moutchia } \\
\text { et al., } 2020\end{array}$ & $\begin{array}{l}\text { October 01, } \\
2020\end{array}$ & $\begin{array}{l}\text { Systematic } \\
\text { review and } \\
\text { meta- } \\
\text { analysis }\end{array}$ & COVID-19 & $\begin{array}{l}\text { Clinical laboratory } \\
\text { parameters of severe or } \\
\text { critical COVID-19 }\end{array}$ & $\begin{array}{l}\text { MEDLINE, EMBASE, Web of } \\
\text { Science, CINAHL and Google } \\
\text { Scholar databases }\end{array}$ & Heterogenous & 1722 & 45 & $\begin{array}{l}\text { April, } \\
18 \\
2020\end{array}$ & 9508 & $\begin{array}{l}\text { China, USA, France, } \\
\text { Germany, Japan and } \\
\text { Singapore }\end{array}$ \\
\hline 13. & $\begin{array}{l}\text { Jahrami } \\
\text { et al., } 2021\end{array}$ & $\begin{array}{l}\text { October 13, } \\
2020\end{array}$ & $\begin{array}{l}\text { Systematic } \\
\text { review and } \\
\text { meta- } \\
\text { analysis }\end{array}$ & COVID-19 & $\begin{array}{l}\text { Impact of COVID-19 } \\
\text { pandemic on quantity or } \\
\text { quality of sleep }\end{array}$ & $\begin{array}{l}\text { PubMed, MEDLINE, Web of } \\
\text { Science, Science, Scopus and } \\
\text { others }\end{array}$ & Heterogenous & 371 & 44 & $\begin{array}{l}\text { July 05, } \\
2020\end{array}$ & 54231 & $\begin{array}{l}\text { China, Iraq, Germany, } \\
\text { India, Italy, France, } \\
\text { Mexico, Spain, } \\
\text { Bahrain, Greece, } \\
\text { Australia and Canada }\end{array}$ \\
\hline 14. & $\begin{array}{l}\text { Mudatsir } \\
\text { et al., } 2020\end{array}$ & $\begin{array}{l}\text { November 02, } \\
2020\end{array}$ & $\begin{array}{l}\text { Systematic } \\
\text { review and } \\
\text { meta- } \\
\text { analysis }\end{array}$ & COVID-19 & $\begin{array}{l}\text { Clinical manifestations } \\
\text { and laboratory findings } \\
\text { of mild to severe } \\
\text { COVID-19 }\end{array}$ & $\begin{array}{l}\text { PubMed, EMBASE, Cochrane, } \\
\text { Web of science }\end{array}$ & Heterogenous & 39 & 19 & $\begin{array}{l}\text { April } \\
05 \\
2020\end{array}$ & 3578 & $\begin{array}{l}\text { China (cities-Wuhan, } \\
\text { Shenzen, Fuyang and } \\
\text { Chongqing) }\end{array}$ \\
\hline 15. & $\begin{array}{l}\text { Mesas et al., } \\
2020\end{array}$ & $\begin{array}{l}\text { November 03, } \\
2020\end{array}$ & $\begin{array}{l}\text { Systematic } \\
\text { review and } \\
\text { meta- } \\
\text { analysis }\end{array}$ & COVID-19 & $\begin{array}{l}\text { Predictors of in-hospital } \\
\text { mortality }\end{array}$ & $\begin{array}{l}\text { PubMed, MEDLINE, Web of } \\
\text { Science, Science, Scopus }\end{array}$ & Heterogenous & 12254 & 60 & $\begin{array}{l}\text { May } \\
17 \\
2020\end{array}$ & 51225 & $\begin{array}{l}\text { China, Italy, Israel, } \\
\text { Pakistan, Brazil, Spain } \\
\text { UK, Switzerland, } \\
\text { France, USA, South } \\
\text { Korea and Iran }\end{array}$ \\
\hline
\end{tabular}


No.

Date of

Methodology

(or acceptance
for publication)

for publication

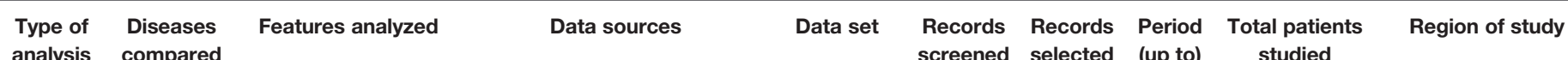

16. Izcovich November 17,
et al., 2020 (2020

analysis compared

screen

Systematic

Prognostic factors for

PubMed, MEDLINE, EMBASE, Heterogenous

569

meta-

severity and mortality CENTRAL

analysis

17. Del Zompo December,

Systematic COVID-19

(n)

$$
\begin{aligned}
& \text { review and } \\
& \text { meta- } \\
& \text { analysis }
\end{aligned}
$$
18. Hannum December 05 et al., 2020

$2020 \quad \begin{aligned} & \text { review and } \\ & \text { meta- } \\ & \text { analysis }\end{aligned}$

$$
\text { analysis }
$$

19. Israfil et al., January 11, Systematic COVID-19 Clinical characteristics

$\begin{array}{ll}2021 & 2021 \\ \text { Poly et al., } & \text { February 05, }\end{array}$

$\begin{array}{lll}2021 & 2021 & \begin{array}{l}\text { Systematic } \\ \text { review and } \\ \text { meta- } \\ \text { analysis }\end{array}\end{array}$

Systematic
review
Systematic
review and
meta-
analysis
Prevalence of liver injury and in-hospital fatality

PubMed, MEDLINE, PMC,
EMBASE, Web of Science,

clinical trial registries,

publications from ArXiv,

BioRxiv, Elsevier, MedRxiv,

$\mathrm{WHO}$ sources and other

databases searched for

coronavirus family publications
19
Google Scholar

PubMed, MEDLINE and

Ap
28,
202

April 57044

China, USA, Canada,

Spain, France, Turkey,

Korea, Japan, Italy,

Germany, India and

Singapore

China, USA, Italy,

\begin{tabular}{|c|c|c|c|c|c|c|}
\hline $\begin{array}{l}\text { PubMed, MEDLINE and } \\
\text { Google Scholar }\end{array}$ & Heterogenous & 43 & 34 & $\begin{array}{l}\text { April } \\
30 \\
2020\end{array}$ & 19746 & $\begin{array}{l}\text { China, Italy, Sweden, } \\
\text { Iran, Germany, Israel, } \\
\text { Switzerland, UK, USA } \\
\text { Taiwan, Korea, } \\
\text { Belgium, Spain, } \\
\text { France, Australia, } \\
\text { Singapore and Iceland }\end{array}$ \\
\hline $\begin{array}{l}\text { PubMed, Web of Science, } \\
\text { Scopus, Science Direct, and } \\
\text { Google Scholar }\end{array}$ & Heterogenous & 557 & 34 & $\begin{array}{l}\text { May } \\
07, \\
2020\end{array}$ & 10889 & $\begin{array}{l}\text { China, USA, Italy, } \\
\text { Singapore, UK, } \\
\text { France, Japan and } \\
\text { Macau }\end{array}$ \\
\hline $\begin{array}{l}\text { PubMed, EMBASE, Google } \\
\text { Scholar, Web of Science, and } \\
\text { Scopus }\end{array}$ & Heterogenous & 252 & 17 & $\begin{array}{l}\text { August } \\
30, \\
2020\end{array}$ & 543399 & $\begin{array}{l}\text { China, Italy, Mexico, } \\
\text { USA, France and UK }\end{array}$ \\
\hline
\end{tabular}

South Korea, France

and Germany

associated Scholar, Web of Science, and

comorbidities and other Scopus

factors on risk of

COVID-19 related

mortality

CENTRAL, Cochrane Central Register of Controlled Trials; CINAHL, Cumulative Index of Nursing and Allied Health Literature; CKNI, China National Knowledge Infrastructure; COVID-19, coronavirus disease 2019; EMBASE, Excerpta Medica database; MEDLINE, Medical Literature Analysis and Retrieval System Online; PMC, PubMed Central; UK, United Kingdom; USA, United States of America. 
These pre-existing comorbidities were found to be linked with the severity of COVID-19 (relative risk, $\mathrm{RR}=2.11, \mathrm{p}=0.046$ ) (Jutzeler et al., 2020). Also, hypertension $(\mathrm{RR}=2.15, \mathrm{p}<0.001)$, diabetes $(\mathrm{R} R=2.56, \mathrm{p}=0.005)$, any heart condition $(\mathrm{RR}=4.09, \mathrm{p}<$ $0.001)$ and chronic obstructive pulmonary disease (COPD) $(\mathrm{RR}=$ $5.10, \mathrm{p}<0.001)$ were associated with adverse disease outcome. In addition, disease severity was more in male $(R R=1.11, p=0.039)$ and old age patients (standardized mean difference, $\mathrm{SMD}=0.68$, $\mathrm{p}<0.001$ ) (Jutzeler et al., 2020). The meta-analysis revealed that older age $(\mathrm{SMD}=1.25,95 \% \mathrm{CI} 0.78-1.72, \mathrm{p}<0.001)$, male gender $(\mathrm{RR}=1.32,95 \% \mathrm{CI} 1.13-1.54, \mathrm{p}=0.005)$ and pre-existing comorbidities $(\mathrm{RR}=1.69,95 \% \mathrm{CI} 1.48-1.94, \mathrm{p}<0.001)$ were associated with less survival. Furthermore, mechanical ventilation was also more frequently required for treatment of non-survivors as compared to survivors ( $R R=6.05$, 95\% CI 1.41 26.05, $\mathrm{p}=0.026)$; with more common administration of extracorporeal membrane oxygenation $(\mathrm{RR}=4.39,95 \% \mathrm{CI}$ $1.64-11.78, \mathrm{p}=0.014$ ) in the non-survivors (Jutzeler et al., 2020). The risk of developing complications during the course of COVID-19 was higher in the non-survivors as compared to the survivors. The complications included, in particular, acute kidney injury (AKI) $(\mathrm{RR}=20.77,95 \% \mathrm{CI} 2.43-177.44, \mathrm{p}=0.017)$ and acute respiratory distress syndrome (ARDS) $(\mathrm{RR}=4.24,95 \%$ CI 1.30-13.83, $\mathrm{p}=0.026$ ) (Jutzeler et al., 2020).

Liver injury has been reported as another comorbidity being associated with the severity and in-hospital fatality of COVID-19 patients. In a meta-analysis of 20724 COVID-19 confirmed cases from 36 articles, pre-existing liver disease was present in up to $37.6 \%$ of cases (Del Zompo et al., 2020) at the time of hospital admission. The etiology of abnormal liver function was mentioned in only a few of the studies analyzed in the said meta-analysis. The authors recommended frequent testing of liver function test (LFT) markers as an additional tool for early stratification and monitoring of COVID-19 patients (Del Zompo et al., 2020). Further prospective cohort investigations are needof-the-hour to validate the significance of LFT biochemistries in the management of COVID-19. Likewise, about 4.5\% of COVID19 patients displayed pre-known viral hepatitis in a study conducted by a different research group (Gu et al., 2020).

Another noteworthy comorbidity is AKI. In view of this, a systematic review and meta-analysis was conducted involving 24527 COVID-19 patients, where the overall rate of severe COVID-19 and COVID-19 related fatality was $26.4 \%$ and $20.3 \%$, respectively (Shao et al., 2020). The robust meta-analysis revealed significant association of AKI with severity $(O R=8.11,95 \%$ CI 5.0113.13, $\mathrm{p}<0.00001)$ and fatality $(\mathrm{OR}=14.63,95 \% \mathrm{CI} 9.94-21.51, \mathrm{p}<$ 0.00001) in COVID-19 patients. Prevalence of severe COVID-19 and fatality due to COVID-19 was considerably high $(55.6 \%$ and $63.1 \%$ respectively, $\mathrm{p}<0.01$ ) in patients with $\mathrm{AKI}$ as compared to those without AKI (17.7\% and $12.9 \%$ respectively) (Shao et al., 2020). Cardiac impairment was a significant factor associated with severe COVID-19 outcomes (OR=3.15, 95\% CI 2.26- 4.41) and fatality $(\mathrm{OR}=1.95,95 \%$ CI 1.08- 3.54) (Figliozzi et al., 2020; Li et al., 2020). Smoking $(\mathrm{OR}=2.24,95 \%$ CI 1.40 - 3.58), history of diabetes mellitus $(\mathrm{OR}=2.34,95 \%$ CI 1.64- 3.33), $\mathrm{COPD}(\mathrm{OR}=2.63,95 \% \mathrm{CI} 1.55-4.44)$ or hypertension $(\mathrm{OR}=2.25,95 \% \mathrm{CI} 1.80-2.82)$ contributed to progression to adverse COVID-19 (Figliozzi et al., 2020). Diabetes mellitus $(\mathrm{OR}=1.74,95 \% \mathrm{CI} 1.22-2.48)$, cardiovascular disease $(\mathrm{OR}=$ 1.95, 95\% CI 1.08- 3.54), COPD (OR=2.98, 95\% CI 1.38-6.44), or cerebrovascular disease $(\mathrm{OR}=2.93,95 \% \mathrm{CI} 1.84-4.26)$ indicated high mortality risk (Figliozzi et al., 2020).

Apart from the above-mentioned somewhat obvious comorbidities, obesity emerged as another major condition that would worsen the outcomes in COVID-19 patients (Földi et al., 2020; Poly et al., 2021). A meta-analysis involving 2770 patients revealed that obesity was a significant risk factor associated with admission to critical care units $(\mathrm{OR}=1.21,95 \%$ CI $1.002-1.46)$ (Földi et al., 2020). Also, the requirement of invasive mechanical ventilation (IMV) was more (up to 78\%) for obese patients as analyzed in 509 subjects. A body-mass-index (BMI) of $\geq 25$ was a significant risk factor for IMV requirement $(\mathrm{OR}=2.63$, 95\% CI 1.644.22) (Földi et al., 2020). Like obesity, psychiatric comorbidities (like anxiety and depression) must also be considered during COVID-19 management. Potential bi-directional associations between psychiatric comorbidities and sleep have been reported (Jahrami et al., 2021), amounting to sleep problems during COVID-19. This may impact the recovery from the disease.

\section{Biochemical Biomarkers as Independent Predictors of Severity, Adverse Prognosis or Mortality of COVID-19}

Recent evidence highlighted the relevance of various biochemical tests as independent or combined correlates for the determination of severity, poor prognosis or mortality related to COVID-19. Clinical laboratory tests encompassing biochemical, hematological, inflammatory and coagulation parameters were considered useful to recognize severe or critical COVID-19. Additionally, these parameters also provided valuable clinical information for effective monitoring of the clinical course of COVID-19. As per findings of a large meta-analysis of 45 studies across 6 countries, neutrophilia (meta-median difference, MMD $=1.23 \times 10^{9} \mathrm{cells} / \mu \mathrm{l}$ ) and lymphopenia $\left(\mathrm{MMD}=-0.39 \times 10^{9} \mathrm{cells} / \mu \mathrm{l}\right)$ were associated with critical COVID-19 (Moutchia et al., 2020). Similar findings were also reported in another meta-analysis comprising 4969 patients (Henry et al., 2020). In this meta-analysis, reduced lymphocyte count and increased neutrophil count at the time of admission were significantly associated with progression to severe disease $(\mathrm{OR}=4.20,95 \%$ CI $3.46-5.09$ and $\mathrm{OR}=7.99,95 \%$ CI $1.77-36.14$, respectively), and mortality $(\mathrm{OR}=3.71,95 \% \mathrm{CI}, 1.63-8.44$ and $\mathrm{OR}=7.87,95 \%$ CI 1.75- 35.35, respectively) (Henry et al., 2020). Inflammatory markers, namely, C-reactive protein (CRP), Interleukin 6 (IL-6), and erythrocyte sedimentation rate (ESR) $(\mathrm{MMD}=36.97 \mathrm{mg} / \mathrm{l}, 17.37 \mathrm{pg} / \mathrm{ml}, 21.93 \mathrm{~mm} / \mathrm{hr}$, respectively) were raised in severe COVID-19 cases (Moutchia et al., 2020). Biochemical indices like alanine aminotransferase (ALT), aspartate aminotransferase (AST), blood urea nitrogen (BUN), creatinine $(\mathrm{MMD}=6.89 \mathrm{u} / \mathrm{l}, 11.96 \mathrm{u} / \mathrm{l}, 1.04 \mathrm{mmol} / \mathrm{l}, 4.87 \mu \mathrm{mol} / \mathrm{l})$ were significantly elevated in severe or critical cases in comparison to non-severe COVID-19 patients (Moutchia et al., 2020). A meta-regression analysis observed that higher leukocyte counts $(p<0.0001)$, elevated levels of ALT $(p=0.024)$, AST $(p=$ 
$0.0040)$, lactate dehydrogenase $(\mathrm{LDH})(\mathrm{p}<0.0001)$ and raised procalcitonin $(\mathrm{PCT})(\mathrm{p}<0.0001)$ were note-worthy predictors of admission to intensive care unit (Zhang JJY. et al., 2020). Further, the researchers found that elevated LDH $(\mathrm{p}<0.0001)$ and high leukocyte counts $(p=0.0005)$ were significantly associated with COVID-19 led mortality. Other laboratory parameters that were found to be significantly associated with critical disease were myocardial biomarkers, Troponin I $(\mathrm{MMD}=0.01 \mathrm{ng} / \mathrm{ml})$, and creatine kinase- $\mathrm{MB}(\mathrm{CK}-\mathrm{MB})(\mathrm{MMD}=1.46 \mathrm{u} / \mathrm{l})$, tissue damage marker, $\mathrm{LDH}(\mathrm{MMD}=124.26 \mathrm{u} / \mathrm{l})$, platelet count $(\mathrm{MMD}=-21.48 \mathrm{x}$ $10^{9}$ cells $/ \mathrm{l}$ ) and $\mathrm{D}$-dimer $(\mathrm{MMD}=0.65 \mathrm{mg} / \mathrm{ml})$ (Moutchia et al., 2020). These laboratory parameters indicated that innate immune response gets activated during COVID-19 as indicated by markedly raised neutrophil to lymphocyte ratio (NLR) and CRP. In contrast, adaptive immune response is unable to limit virus replication during severe COVID-19, as evidenced by reduced levels of lymphocytes and its subsets. Thus, routine testing for NLR, CRP, ESR, Troponin-I, BUN, creatinine, AST, ALT, CK-MB, LDH and D-dimer in severe COVID-19 is beneficial in monitoring clinical progression and can predict outcome of the disease. Anisocytosis, a condition that is characterized by heterogeneity in volumes of circulating red blood cells (RBCs), has also been linked to severe COVID-19. This low-cost parameter is expressed as RBC distribution width (RDW) and may be calculated as either RDWstandard deviation (SD) or coefficient of variation $(\mathrm{CV})$. In this view, an analysis of RDW in 11445 COVID-19 patients was conducted and a $0.69 \%$ increase $(95 \%$ CI $0.40-0.98, \mathrm{p}<0.001)$ in absolute RDW-CV value of severe COVID-19 patients was found in comparison to mildly ill COVID-19 patients (Lippi et al., 2020). Hence, estimation of RDW may assist in risk stratification of adverse COVID-19 progression (Lippi et al., 2020).

Laboratory results were useful in differentiating severe from non-severe COVID-19 patients at the time of admission to the intensive care unit, as per the systematic review and meta-analysis conducted by Ghahramani et al. (Ghahramani et al., 2020). Results of routine tests like LFT, kidney function tests (KFT), glucose, albumin, electrolytes and complete blood count (CBC) were significantly altered in severe or critical COVID-19 patients belonging to the Asian population. In the same systematic review and meta-analysis, elevated PCT levels and higher neutrophil count were associated with bacterial co-infection in severe COVID-19 patients. Further, sensitivity analysis revealed significant differences in pooled effect size (p-ES) for NLR, lymphocyte to CRP ratio (LCR), PCT, AST, ALT, sodium, glucose, BUN, creatinine, ESR, myoglobin and D-dimer (Ghahramani et al., 2020). Laboratory parameters like decreased platelet count $(\mathrm{p}-\mathrm{ES}=-1.7)$, low hemoglobin concentration ( $\mathrm{p}-\mathrm{ES}=-0.6)$, low albumin $(\mathrm{p}-\mathrm{ES}=$ -3.1), raised IL-6 (p-ES = 2.4), elevated creatinine $(\mathrm{p}-\mathrm{ES}=2.4)$ and higher troponin-I ( $\mathrm{p}-\mathrm{ES}=0.7)$ were markedly associated with in-hospital mortality (Mesas et al., 2020). As per another metaanalysis, low albumin levels $(\mathrm{SMD}=-1.13,95 \% \mathrm{CI}-1.41--0.85, \mathrm{p}<$ $0.001)$ and lymphocyte counts $(\mathrm{SMD}=-0.92,95 \% \mathrm{CI}-1.3--0.55$, $\mathrm{p}<0.001)$ as well as high IL-6 levels (SMD $=1.21,95 \%$ CI $0.93-1.5$, $\mathrm{p}<0.001$ ), leucocyte counts $(\mathrm{SMD}=2.21,95 \%$ CI $0.61-3.64, \mathrm{p}=$ $0.06)$, and prolonged prothrombin time (SMD $=7.99,95 \% \mathrm{CI} 4.64-$ 11.34, $\mathrm{p}<0.01$ ) were found to be linked with COVID-19 related mortality (Jutzeler et al., 2020). Hence, abnormal indices of the above-mentioned parameters could be prognostic markers of adverse COVID-19 outcomes.

In another large-scale analysis, including more than 57000 COVID-19 patients, 49 parameters were identified as high/ moderate predictors of poor prognosis (Izcovich et al., 2020). The variable parameters included demographic factors: increasing age, male gender and smoking; comorbidities: diabetes, cerebrovascular disease, COPD, cardiovascular disease, cardiac arrhythmia, arterial hypertension, chronic kidney disease, cancer, dementia and dyslipidemia; physical examination factors: respiratory failure, fever, myalgia or arthralgia, fatigue, abdominal pain, tachycardia, hypoxemia, dyspnea, anorexia, tachypnoea, low blood pressure, hemoptysis; laboratory assessments: elevated PCT, myocardial injury markers, increased WBC counts, elevated blood lactate, reduced lymphocyte count, reduced platelet count, increased neutrophil count, raised plasma creatinine, elevated D-dimer, raised $\mathrm{LDH}$, elevated CRP, raised AST levels, decreased albumin, elevated IL-6 levels, raised B-type natriuretic peptide (BNP), elevated BUN, raised ESR, elevated $\mathrm{CK}$ and raised bilirubin; radiological factors: pleural effusion and consolidative infiltrate; and high sequential organ failure assessment (SOFA) score (Tables 1B, 2) (Izcovich et al., 2020).

A systematic review and meta-analysis of 36 studies involving more than 20000 patients demonstrated important findings (Del Zompo et al., 2020). With an intent to correlate liver injury with clinical outcomes in COVID-19 patients, the researchers found that nearly $47 \%$ of COVID-19 cases had abnormal LFT. They also found that the laboratory tested AST, ALT and total bilirubin were independent predictors of COVID-19 severity and in-hospital mortality (Table 2) (Del Zompo et al., 2020). However, there was insufficient information on the etiology of pre-existing liver injury in COVID-19 patients at the time of hospitalization. Hence, further prospective cohort studies would be essential to validate these findings.

Other noteworthy biochemical findings are elevated levels of BUN and serum creatinine (SCr) (Shao et al., 2020). A robust meta-analysis recorded significant $(\mathrm{p}<0.00001)$ rise in levels of BUN and SCr in severe COVID-19 cases and non-survivors (Table 1B) (Shao et al., 2020). Increased SCr and BUN values were identified as independent biomarkers for COVID-19 related severity and in-hospital mortality early during the pandemic (Chen et al., 2020; Cheng et al., 2020). However, the rate of severe and fatal cases in the study by Shao et al. was quite high, which could be due to the fact that the studies analyzed represented majorly poor COVID-19 outcomes (Shao et al., 2020). Hence, over-estimation of severity and fatality rate may be a limitation to this otherwise crucial set of findings.

\section{Radiological Investigations}

Identification of viral pathogens is possible by careful examination of imaging patterns since the latter are associated with viral pathogenesis. Since, viruses belonging to a single viral family share a similar pathogenesis, computed tomography (CT) was considered a trusted technique to distinguish patterns and features of COVID-19 in immunocompetent patients (Chung 


\section{Most \\ - Most}

1. Zhang JJY.
et al., 2020 males (66.5\%) vs. females (33.5\%) suffered from fever $(80.5 \%$, patients analyzed $=3934)$, cough $(58.3 \%$, patients cardiovascular diseases analyzed $=3718)$ and dyspnea;

$(12.1 \%$, patients analyzed $=$

dyser 1498 ) and diabetes mellitus

- Pooled analyzed=2992); 3060).

mean age: $45 \quad-\quad$ Fever definition as

years $\left(95 \% \mathrm{Cl}, \quad \geq 37.3^{\circ} \mathrm{C}\right.$ (7 studies) or

35.5- $54.5 \geq 37.5^{\circ} \mathrm{C}$ (2 studies);

years; $\quad$ Pooled mean

- ICU incubation period: 6.1

admission: days (95\% Cl 5.0-7.3

$10.9 \%$, patients days)

analyzed $=$ - Pooled mean time

2153.

from onset of

- Mortality: symptoms to hospital

$4.3 \%$, patients admission: 7.2 days

analyzed $=\quad(95 \% \mathrm{Cl} 5.5-8.9$ days $)$
- Most common:

Hypertension $(16.4 \%$ patients analyzed $=2928$ ),

- Most common: Increased levels of CRP

59.4\%) and lactate dehydrogenase (LDH) $(51.7 \%)$, low levels of albumin (58.6\%) and lymphopenia (47.7\%).

$.8 \%$, patients analyzed $=$

3060).
Bilateral

infiltrates

(80.8\%),

opacities

2618),

and et al., 2020

ground-glass

(73.0\%, patients

analyzed $=$

interlobular

septal thickening

(46.3\%, patients

analyzed $=522$ )

subpleural lines

(45.5\%, patients

analyzed $=245$ )

consolidation

(41.6\%, patients

analyzed=

2395).

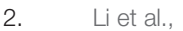

Li et a

$\cdot \quad$ COVID-19
severity not
significantly
linked with
gender $(\mathrm{OR}=$
$1.14,95 \% \mathrm{Cl}$
$0.91-1.43, \mathrm{I}^{2}=$
$0.0 \%, \mathrm{p}=$
$0.267)$ or
Wuhan
exposure
history (OR=
$0.92,95 \% \mathrm{Cl}$
$0.53-1.59, \mathrm{I}^{2}=$
$0.0 \%, \mathrm{p}=$
$0.764) ;$
$\bullet \quad$ Smoking
significantly

- Fever $(\mathrm{OR}=1.67$,

- Severity or ICU $95 \%$ Cl 1.15-2.42, $\mathrm{p}=$ admission related to

$\left.0.007, I^{2}=38.8 \%\right)$ and $\quad$ diabetes $(\mathrm{OR}=3.17,95 \%$ dyspnea $(\mathrm{OR}=4.17$, diabetes $(\mathrm{OR}=3.17,95 \%$ $95 \% \mathrm{Cl} 2.04-8.53, \mathrm{p}<\quad=35.3 \%), \mathrm{COPD}(\mathrm{OR}=$ $\left.0.001, I^{2}=71.3 \%\right) \quad 5.08,95 \% \mathrm{Cl} 2.68-9.63$, related to severe

COVID-19. $\left.\mathrm{P}<0.001, \mathrm{I}^{2}=0.0 \%\right)$ coronary heart disease $(\mathrm{OR}=2.66,95 \% \mathrm{Cl} 1.71$ $\left.4.15, p<0.001, I^{2}=0.0 \%\right)$ hypertension $(\mathrm{OR}=2.40$ $95 \% \mathrm{Cl} 1.47-3.90, \mathrm{p}<$ $\left.0.001, I^{2}=51.5 \%\right)$, cerebrovascular diseases (OR= 2.68, 95\% Cl 1.29$5.57, p=0.008, I^{2}=$

$41.8 \%)$, and malignancy

$\mathrm{OR}=2.21,95 \% \mathrm{Cl} 1.04-$
Severity indicators:

Elevated leucocyte counts $(\mathrm{OR}=3.46$, $\left.95 \% \mathrm{Cl} 1.06-11.28, p=0.040, \mathrm{I}^{2}=75.1 \%\right)$ PCT (OR= 6.69, 95\% Cl 3.99- 11.20, $p \leq$ $\left.0.001, I^{2}=13.6 \%\right), \operatorname{CRP}(\mathrm{OR}=4.02,95 \% \mathrm{Cl}$ 2.80- 5.79, $\left.p \leq 0.001, I^{2}=11.1 \%\right), \mathrm{LDH}$ (OR= $3.36,95 \% \mathrm{Cl} 2.46-4.58, \mathrm{p}<0.001, \mathrm{l}^{2}=$ $48.3 \%)$, AST (OR= 3.26, 95\% Cl 2.40-4.42, $\left.P<0.001, I^{2}=5.3 \%\right), A L T(O R=1.95,95 \% C$ 1.35- 2.80, $\left.p<0.001,\left.\right|^{2}=39.6 \%\right)$, Creatinine $\left(\mathrm{OR}=2.14,95 \% \mathrm{Cl} 1.14-4.01, \mathrm{p}=0.018, \mathrm{I}^{2}=\right.$ $0.0 \%)$, CK (OR=2.45, 95\% Cl 1.69- 3.55, p< $\left.0.001, I^{2}=46.7 \%\right)$

.82, $95 \% \mathrm{CI}$ .07-3.83, $\left.p<0.001, L^{2}=0.0 \%\right)$ and

lymphocytes $(\mathrm{OR}=4.60,95 \% \mathrm{Cl} 3.25-6.51$, $\mathrm{p}<0.001, \mathrm{I}^{2}=0.0 \%$ )

\begin{tabular}{|c|c|}
\hline 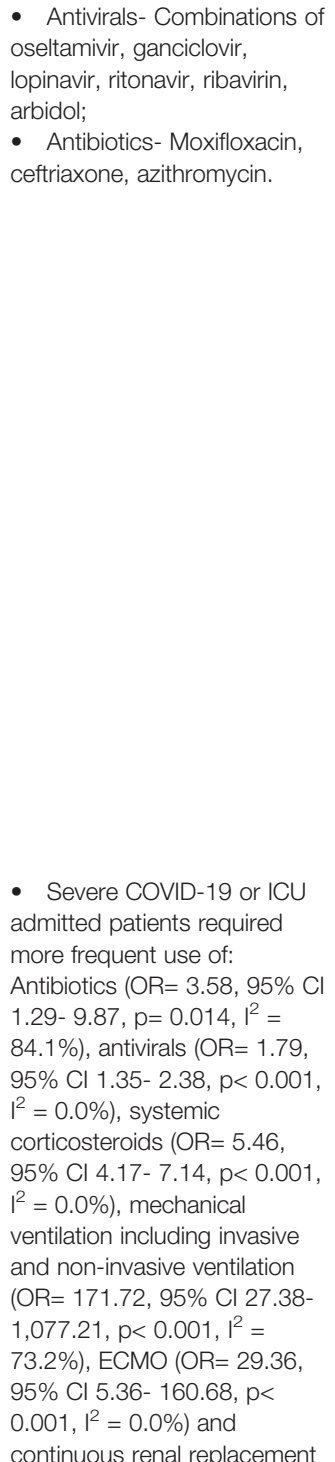 & $\begin{array}{l}\text { - High counts of } \\
\text { leukocytes, high } \\
\text { levels of ALT, AST, } \\
\text { LDH, and PCT are } \\
\text { important } \\
\text { laboratory markers } \\
\text { that are associated } \\
\text { with ICU } \\
\text { admission, } \\
\text { mortality and } \\
\text { ARDS; } \\
\text { - Use of } \\
\text { corticosteroids is } \\
\text { significantly } \\
\text { associated with } \\
\text { higher proportion } \\
\text { of patients with } \\
\text { ARDS; } \\
\text { - Use of lopinavir } \\
\text { and ritonavir is not } \\
\text { distinctly related to } \\
\text { lowering mortality } \\
\text { due to COVID-19; } \\
\text { - Further } \\
\text { prospective studies } \\
\text { are necessary to } \\
\text { validate the } \\
\text { findings. } \\
\text { - Significant } \\
\text { differences in } \\
\text { outcome of severe } \\
\text { and non-severe } \\
\text { pneumonia in } \\
\text { terms of discharge } \\
\text { and death were } \\
\text { observed. }\end{array}$ \\
\hline
\end{tabular}


Demographics Signs and symptoms

Comorbidities

Laboratory findings

Radiological
(CT scan)

findings

severe COVID-

$19(\mathrm{OR}=1.70$,

$95 \%$ Cl: $1.20-$

$2.41, I^{2}=$

$43.4 \%, p=$

0.003).

3. Földi et al., $2020 \quad 9 \%$ to $43 \%$

(2,770 patients

from 6 studies)

patients

required ICU

admission;

- A range of

$58 \%$ to $78 \%$

(509 patients

from 5 studies

required IMV.

\begin{abstract}
- Obesity significantly
associated with higher risk

for ICU admission (OR=

$1.21,95 \% \mathrm{Cl} 1.002-1.46$,

$\left.1^{2}=0.0 \%\right)$

- Obesity associated with

higher risk for IMV $(\mathrm{OR}=$

$2.05,95 \% \mathrm{Cl} 1.16-3.64, \mathrm{I}^{2}$

$=34.86 \%$;

6 times higher risk for

$\mathrm{ICU}$ admission in patients

with $\mathrm{BMl} \geq 35$ as compared

$\mathrm{BM}<25(\mathrm{OR}=6.16$
\end{abstract}

NA

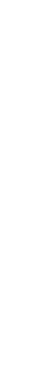

$\begin{array}{llll}\text { Lu et al., } & \text { - Higher } & \text { - Respiratory rate } & \text { - Chronic lung disease, } \\ 2020 & \text { mortality rates } & \text { was a sensitive } & \text { hypertension, diabetes, } \\ \text { in elderly (total } & \text { indicator of mortality for } & \text { increasing age and male } \\ & \text { OR=7.86, 95\% } & \text { COVID-19 (OR=4.90, } & \text { gender. } \\ \text { Cl 5.46- 11.29; } & 95 \% \text { Cl 1.08-22.24) } & \\ \text { COVID-19: } & \text { and SARS (OR=8.88, } & \\ \text { OR=6.45, 95\% } & \text { 95\% Cl 5.64- 13.97). }\end{array}$

$95 \% \mathrm{Cl} 0.24-0.44)$, lower lymphocyte cound

$\begin{array}{ll}95 \% \mathrm{Cl} 0.24-0.44) \text {, lower lymphocyte counts } & \text { consolidation } \\ \mathrm{OR}=0.21,95 \% \mathrm{Cl} 0.12-0.38) \text {, higher } & \text { and bilateral }\end{array}$

- Similar

pulmonary

(O)

raised WBC count $(\mathrm{OR}=9.13,95 \% \mathrm{Cl} 5.71$ -

14.59), decreased albumin levels ( $O R=0.11$, therapy $(\mathrm{OR}=25.45,95 \% \mathrm{C}$

6.97-92.89, $p<0.001, I^{2}=$

$0.0 \%)$.

- Significantly higher

- Obesity may

likelihood of IMV requirement in serve as important patients with $\mathrm{BM} \geq 25$ as

clinical predictor of

compared to $\mathrm{BMl}<25(\mathrm{OR}=\quad$ risk gradation for

2.63, 95\% Cl 1.64- 4.22, $I^{2}=$ COVID-19, and

$0.0 \%)$.

related ICU

admission,

especially IMV

requirement;

- Higher BM

ranges carried

significantly higher

risk for IMV in

contrast to lower

BMl ranges;

- Careful

monitoring of

obese patients is

necessary to better

manage COVID-19;

- Early escalation

of therapy may be

needed in such

patients to dodge

unfavorable clinical

outcomes;

- High

recommendation to

improve guidelines

for patients with

obesity owing to

the returning

pandemic waves.

- Mortality

indicators for

COVID-19 are

similar to SARS

and MERS. 
Demographics Signs and symptoms

Comorbidities

Laboratory findings

Radiological
(CT scan)

findings

\section{Cl 3.86- 10.77}

SARS: OR=

$11.97,95 \% \mathrm{Cl}$

8.82- 16.24;

MERS: OR=

$7.02,95 \% \mathrm{Cl}$

4.59-10.73);

- Among the

non-survivors,

higher mortality

rate observed in

males (total

$\mathrm{OR}=1.82,95 \%$

Cl 1.56- 2.13;

COVID-19:

$\mathrm{OR}=1.96,95 \%$

Cl 1.43- 2.69;

SARS: $\mathrm{OR}=$

$1.81,95 \% \mathrm{Cl}$

1.43- 2.30;

MERS: OR=

$1.74,95 \% \mathrm{Cl}$

1.32- 2.30).

Higher mortality

rate observed in

patients with

comorbidities

(total $\mathrm{OR}=4.41$,

- $95 \% \mathrm{Cl}$

3.18- 6.12;

COVID-19:

$\mathrm{OR}=3.50,95 \%$

Cl 2.35- 5.20;

SARS:

- $\mathrm{OR}=6.47$,

$95 \% \mathrm{Cl} 4.93-$

8.50: MERS.

8.50; MERS:

$\mathrm{OR}=3.08,95 \%$$$
\text { - Patients }
$$

aged above 70

years had 13-

fold higher

odds of death

than younger

patients $(\mathrm{OR}=$

- Non-productive

- Diabetes mellitus $(\mathrm{OR}=$

$1.74,95 \% \mathrm{Cl} 1.22-2.48, \mathrm{n}$
$=13)$, history of CVD (OR=

$1.95,95 \% \mathrm{Cl} 1.08-3.54$, n

$=7$ ) or cerebrovascular

disease $(\mathrm{OR}=2.93,95 \% \mathrm{C}$

1.84- $4.26, n=5)$,
95\% Cl 0.06- 0.19), raised $\mathrm{LDH}(\mathrm{OR}=37.52$,

$95 \% \mathrm{Cl} 24.68-57.03$ ), elevated CRP (OR=

$12.11,95 \% \mathrm{Cl} 5.24-27.98)$ and elevated

BUN (OR= 8.49, 95\% Cl 5.81- 12.40);

- Mortality indicators for all 3 coronavirus

diseases, i.e., SARS, MERS and COVID-19:

$\mathrm{LDH}$, neutrophils, CRP, BUN and albumin;

- Higher variation among laboratory

parameters in COVID-19 as compared to

SARS and MERS.

\section{- Majority of}

the COVID-19

patients with

above-said

abnormal

imaging features

died

(consolidation:

$\mathrm{OR}=3.26,95 \%$

Cl 1.16- 9.13

GGO: OR=

$1.45,95 \% \mathrm{Cl}$

$0.47-4.49)$.
- During acute phase: steroids, antibiotics and antivirals.
- High odds of mortality indicated

by various

omorbidities,

laboratory findings and increasing age. 
Demographics Signs and symptoms

Comorbidities

Laboratory findings

Radiological
(CT scan)

Therapies

findings

$13.19,95 \% \mathrm{Cl}$

7.72- 22.55);

- Males had

higher risk of

death $(\mathrm{OR}=$

$1.71,95 \% \mathrm{Cl}$

1.39- 2.09, $\mathrm{p}<$

0.001).

lymphopenia:

Number of tota

patients range

from $12(6$

severe) to 1099

(153 severe);

females: $15 \%$

to $50 \%$; age

range of severe

cases: 25 to 87

years;

- Fatal

lymphopenia:

Number of total

patients ranged

from 108 (96

non-survivors)

to 274 (113

hypertension $(\mathrm{OR}=2.71$

95\% Cl 1.99- 3.69, $n=15$

and $\mathrm{COPD}(\mathrm{OR}=2.98$,

$95 \%$ Cl 1.38-6.44, $n=8$ )

associated with higher risk

of mortality;

- Progressing age

associated with worse

prognosis $(\mathrm{p}-\mathrm{OR}=1.02$

per year, $95 \% \mathrm{Cl} 1.00$

1.06, $p=0.069$ )

- Hypertension identified

as an overall link between

increasing age and worse

prognosis;

Male gender associated

with higher risk of mortality:

- Smoking not a

predictor of mortality $(\mathrm{OR}=$

3.14, 95\% Cl 0.48-20.56,

$\mathrm{n}=4$ ), but only associated

with greater likelihood of

composite adverse

outcome (OR= 2.24 per

comparison to non-

smokers, $95 \% \mathrm{Cl} 1.40-$

3.58, $p=0.003, n=11)$.

$$
\text { NA }
$$

- Admission lymphopenia significantly indicated more than 4-fold increased risk of developing severe COVID-19 (OR= 4.20, 95\% Cl 3.46- 5.09, $p<0.001 ;\left.\right|^{2}=0.0 \%$ ) and inhospital mortality (OR=3.71, 95\% Cl 1.638.44, $\left.p=0.002 ;\left.\right|^{2}=88.4 \%\right) ;$

- Admission neutrophilia significantly linked to 8-fold increased odd of developing severe COVID-19 (OR= $7.99,95 \% \mathrm{Cl} 1.77-36.14$ $\left.\mathrm{p}=0.007, \mathrm{I}^{2}=75.9\right)$ and mortality $(\mathrm{OR}=7.87$, $\left.95 \% \mathrm{Cl} 1.75-35.35, p=0.007, I^{2}=89.3\right)$.
NA
- Lymphopenia and neutrophilia at first visit should be included in risk stratification models;

These are

independent risk

factors for adverse outcome. 
cases: 51 to 84

years;

- Severe

neutrophilia:

Total patients
ranged from 12

(6 severe) to

$548(267$

severe);

Females:

$34.4 \%$ to $50 \%$;

Age range of

severe cases:

38 to 72 years;

- Fata

neutrophilia (2

studies): Total

patients 144

(70 severe) and

274 (113

severe);

Females:

$35.7 \%$ and

27\%; Age

range fata

range of fatal

cases: 62 to 84

7. Shao et al., $\quad$ N

patients ranged

from 41 to

5700, Mean

$45.4 \pm 17.2$ to

69 years;

Males: $38.8 \%$

to $73 \%$.

$\begin{array}{ll}\text { 8. Li et al., } & \text { - Total NA } \\ 2020 & \text { subjects }\end{array}$

analyzed: 4631
- AKI in $10 \%(95 \% \mathrm{Cl} 8-$ 13) COVID-19 patients (with statistical

heterogeneity among the

Higher SCr levels (MD=20.19 $\mu \mathrm{mol} / \mathrm{l}, 95 \% \quad \mathrm{NA}$

Cl 14.96- 25.42, $p<0.00001,\left.\right|^{2}=55 \%$,

Cochran's $Q, p=0.03$ );

studies analyzed, $I^{2}=$

- Higher BUN levels associated with severity

$8 \%$

- AKI significantly

associated with high

mortality $(\mathrm{OR}=14.63,95 \%$

Cl 9.94-21.51, p<

$0.00001, I^{2}=77 \%, p<$

$0.01)$.

NA and mortality.

- Elevated Tnl levels associated with severity NA (64.5\%), ICU admission (56\%) and mortality (59.3\%);
- AKI significantly associated with fatality in COVID-19 patients;

- Kidney damage monitoring crucial during early stage of COVID-19.

- Combination of cardiac

examination and 
Demographics Signs and symptoms

Comorbidities

Laboratory findings

$$
\begin{aligned}
& \text { Radiological } \\
& \text { (CT scan) } \\
& \text { findings }
\end{aligned}
$$

Therapies

\section{Among the}

studies

analyzed

sample size

ranged from 4

to 1099 and

16 studies;

Males: $42.5 \%$

to $73.2 \%$;

Mean/median

age: 43.1 to 62

years.

severe: 2676

\section{Jutzeler \\ - Higher \\ et al., 2020 proportion of \\ males vs. \\ - Most common in \\ adult patients: Fever}

females suffered cough (53.8\%, 4778/
- Mean NT-proBNP levels significantly highe

in patients with elevated Tnl levels $(\mathrm{SMD}=$

1.63, 95\% Cl 1.02- 2.23, $p<0.001 ;\left.\right|^{2}=$

86.6\%) than the ones with non-elevated Tnl;

- Higher mean CK levels significantly

associated with severity/ICU admission (SMD=

$0.39,95 \% \mathrm{Cl} 0.11-0.67, p=0.006 ; \mathrm{I}^{2}=$

$69.0 \%)$

- Elevated CK-MB levels more frequent in

severe COVID-19/ICU-admitted patients

$(45.7 \%)$;

- Higher CK-MB levels associated with

higher risk of severe COVID-19 or ICU

admission ( $R R=3.24,95 \% \mathrm{Cl} 1.66-6.34, p=$ $\left.0.001, I^{2}=79.8 \%\right)$;

- Increased LDH levels in $60.1 \%$ of severe or

ICU-admitted patients;

- Higher LDH levels associated with

increased risk of severity or ICU admission

$\left(\mathrm{RR}=2.20,95 \% \mathrm{Cl} 1.55-3.12, \mathrm{p}<0.001, \mathrm{I}^{2}=\right.$

$79.7 \%)$;

Elevated levels of IL-6 significantly associated

with severity or ICU admission ( $\mathrm{SMD}=0.54$,

$95 \% \mathrm{Cl} 0.27-0.81, \mathrm{p}<0.001, \mathrm{I}^{2}=0.0 \%$ ) and

mortality $(\mathrm{SMD}=1.28,95 \% \mathrm{Cl} 1.00-1.57, \mathrm{p}<$

$\left.0.001, I^{2}=13.7 \%\right)$

- Emerging arrythmia linked to higher risk of severity or ICU admission ( $R R=13.09,95 \%$ C

7.00-24.47, $\mathrm{p}<0.001, \mathrm{I}^{2}=42.0 \%$ ).

- Decreased levels of sodium, lymphocytes,

monocytes, eosinophil, hemoglobin and

platelets, albumin;

- Increased levels of ALT, AST, total bilirubin, BUN, creatinine, CRP, LDH, PCT,

ESR and glucose.

- Most common in adult patients: Hypertension 20.93\%, 1352/6460) heart failure $(10.5 \%, 37 /$

Adults: Elevated levels of IL-6 [22 pg/ml (4.68-51.8)], erythrocyte sedimentation rate [32.5 mm/h (17.3-53.8)], D-dimer [0.5 $\mu \mathrm{g} / \mathrm{m}$ iomarkers can

improve accuracy

of cardiac injury

Careful

monitoring of

monitoring of

cardiac injury

biomarkers during

COVID-19 is

recommended.

NA

NA

- Results of CBC

LFT, KFT,

inflammatory

markers, glucose

and electrolytes

significantly varied

between severe

and non-severe

patients;

- Further studies

in other

populations are

recommended.

- Adults: Pneumonia (unilateral or

- Adults: Antivirals $(73.8 \%$

- Clinical sign

$4475 / 6068)$, oxygen therapy and imaging

$(69.4 \%, 1300 / 1872)$ and features

comparable 
Demographics Signs and symptoms

Comorbidities

Laboratory findings

from COVID-19 8885) and fatigue

across all single $\quad(25 \%, 1996 / 7980)$;

354), diabetes mellitus

LDH [213 u/l (173-268)];

studies

- Most common in

(10.4\%, 678/6535),

analyzed.

pregnant women $\quad(8.5 \%, 194 / 2388)$;

- Pregnant women: Increased levels of

CRP [19.25 mg/l (12.35-25.7)], procalcitonin bronchogram

pr/35),

5 pregnant

$(0.187 \mathrm{ng} / \mathrm{ml})$, neutrophil count $\left(9.14 \times 10^{9} /\right)$

$25 / 35)$, cough $(41.4 \%, \quad$ women patients had

Pectate dehydrogenase $(544 \mathrm{u} / 1)$

(33.3\%, 3/9);

comorbidities, of which 2

- Most common in

generalized conclus

pediatric and

other 3 were:

normative values are age-dependent within

Fever $(53.1 \%, 170 / \quad$ - None in pediatric and

320), cough $(47.9 \%$, neonatal patients, except

149/311) and sputum 2 children.

$(27.5 \%, 14 / 5$

patients);

\section{- Asymptomatic}

patients: Overall $(7.8 \%$,

$\left.297 / 3^{\prime} 822\right)$ including

$5.4 \%$ adult (148/2749)

patients, $14 \%(149$

1054) children and

neonates. Lippi et a

- Only 3

studies with

total 11445

(161 to 11095

range) samples

and 2654

(23.2\%) severe

cases; Females:

$41.3 \%$ to

48.9\%; Mean

age: $39 \pm 13$ to

$65 \pm 7$ years

12. Moutchia - Sample size NA et al., 2020 ranged from 5

to 1582; Mean
- Patients had varied degrees of comorbidities:

\section{- $R$}

\section{illness;}

- Increased RDW at admission carried 2.5fold risk of in-hospital mortality;

- Incremental RDW values in hospitalized

patients associated with increased mortality

- Severe or critical COVID-19 patients

displayed significantly higher counts/levels of WBCs, neutrophils, CRP, IL-6, ESR, ALT,

Radiological
(CT scan)
findings

620/7917),

including air

$(50.5 \%, 264 /$

523) and GGO

consolidation

$(47.4 \%, 153 /$

323) and without

(43.8\%, 2446/

$5591) ;$

\section{- Pregnan}

women

Pneumonia

(unilateral or

bilateral, $88.6 \%$

31/35), GGO

$(85.3 \%, 29 / 34)$

and

consolidation

$(50 \%, 8 / 16)$;

\section{(50\%, 8/16);}

and neonates:

Pneumonia

(65\%, 194/298),

GGO $(38.9 \%$,

$108 / 278)$ and

local patchy

shadowing

(23.3\%, 52/223).

Therapies

\section{5);}

Antibiotics and non-survivors.

(100\%, 14/14), antivirals Pre-existing

(78.6\%, 11/14) and oxygen comorbidities

connula; 25\%, 3/12);

- Pediatrics and neonates: severity;

Antibiotics $(72.1 \%, 31 / 43), \quad$ - Abnormal

oxygen therapy (high flow laboratory tested

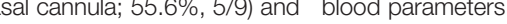

are associated with

cost parameter and can be used for

assessing the risk

progression;

- Further studies

recommended to

analyze if $R D W$ is

also useful to

predict the post-

recovery course of

COVID-19.

NA

- Severe COVID-

19 displays

increased levels of 
Demographics Signs and symptoms

Comorbidities

Laboratory findings

Radiological Therapies
(CT scan)
findings

median age: 35

to 68 years;

Males: $33.3 \%$

to $81 \%$.

hypertension, diabetes and

cancer

AST, serum creatinine, D-dimer and LDH in

comparison to non-severe COVID-19 patients

13.

$\begin{array}{lll}\text { Jahrami } & \text { - Total } & \text { - Global pooled } \\ \text { et al., 2021 } & \text { patients } & \text { NA } \\ & \text { analyzed: } & \text { sleep problems among } \\ & \text { 54231; Study } & \text { all populations: 35.7\% } \\ \text { population } & (95 \% \text { Cl 29.4-42.4); } \\ \text { ranged from } & \text { - COVID-19 patients } \\ \text { general public } & \text { most affected with a } \\ \text { to healthcare } & \text { pooled rate: 74.8\% } \\ \text { workers; Age } & (95 \% \text { Cl 28.7-95.6); } \\ \text { range: 18 to 60 } & \text { - Health care workers } \\ \text { years; Males: } & \text { and general population: } \\ \text { 0\% to 91.5\%. } & \text { comparable rates: } \\ & \text { 36.0\% (95\% Cl 21.1- } \\ & \text { 54.2) and 32.3\% (95\% } \\ & \text { Cl 25.3-40.2), } \\ & \text { respectively. }\end{array}$

14.

\begin{tabular}{|c|c|c|c|}
\hline $\begin{array}{l}\text { Mudatsir } \\
\text { et al., } 2020\end{array}$ & $\begin{array}{l}\text { - Sample size } \\
\text { of severe } \\
\text { patients ranged } \\
\text { from } 7 \text { to } 926 \text {, } \\
\text { while that of } \\
\text { mildly ill patients } \\
\text { ranged from } 10 \\
\text { to } 283 \text {. }\end{array}$ & $\begin{array}{l}\text { - Lower risk of severe } \\
\text { coviD- } 19 \text { due to dry } \\
\text { cough vs. productive } \\
\text { cough (OR= } 0.66,95 \% \\
\text { Cl 0.44- } 0.97) \\
\text { - Higher risk of } \\
\text { severe COVID-19 due } \\
\text { to: Dyspnea (OR= } \\
\text { 3.28, 95\% Cl 2.09- } \\
\text { 5.15), fatigue (OR= } \\
\text { 2.00, 95\% Cl 1.25- } \\
\text { 3.20), anorexia (OR= } \\
\text { 1.83, 95\% Cl } 1.00- \\
\text { 3.34), elevated }\end{array}$ & $\begin{array}{l}\text { - Higher risk of } \\
\text { developing severe form of } \\
\text { COVID-19 due to: Chronic } \\
\text { respiratory disease (OR= } \\
2.48,95 \% \mathrm{Cl} 1.44-4.27) \text {, } \\
\text { cardiovascular disease } \\
\text { (OR=1.70, } 95 \% \mathrm{Cl} 1.05 \text { - } \\
2.78) \text {, diabetes mellitus } \\
(\mathrm{OR}=2.10,95 \% \mathrm{Cl} 1.33- \\
3.34) \text {, and hypertension } \\
(\mathrm{OR}=2.33,95 \% \mathrm{Cl} 1.42- \\
3.81) \text { were associated with } \\
\text { a greater risk of severe } \\
\text { COVID-19 }\end{array}$ \\
\hline
\end{tabular}

- Lower risk of severe COVID-19: low eukocyte levels (OR= $0.59,95 \% \mathrm{Cl} 0.41$ 0.87 ) and elevated lymphocyte $(\mathrm{OR}=0.34$ $95 \% \mathrm{Cl} 0.23-0.50)$

- Higher risk of severe COVID-19 indicators: Elevated WBC count (OR= 4.92, 95\% Cl 2.12-11.31), raised neutrophil count (OR= 5.45, 95\% Cl 2.04- 14.54), Iymphocytopenia hemoglobin levels $(\mathrm{OR}=0.76,95 \% \mathrm{Cl} 0.58$ -

1.00), elevated AST $(O R=4.91)$, elevated ALT

$(\mathrm{OR}=3.23)$, raised $\mathrm{SCr}(\mathrm{OR}=2.14)$, elevated

BUN (OR= 6.15, 95\% Cl 3.05- 12.37), elevated Hs-troponin I (OR= 9.25, 95\% Cl (OR= 3.19, 95\% Cl 1.14-7.07), reduced biomarkers of

innate immune

response, tissue

damage and major

organ failure; and

decreased levels of

biomarkers of

adaptive immune

response.

- High prevalence

$(40 \%)$ of sleep

problems in

patients and

- Sleep self-

assessment

questionnaires, like,

PSQI (39.6\%; 95\%

Cl 29.6- 50.6)

more sensitive to

diagnose sleep

problems

associated with

COVID-19;

- Further

longitudinal studies

required to

understand

trajectories of sleep

problems post-

COVID in different

populations.

- COVID-19

exhibits an

unknown pattern of

disease

development;

- 34 factors

associated with

severe COVID-19

were identified in

the systematic

review and meta-

analysis;

- These factors

may improve the 


\section{Demographics Signs and symptoms}

Comorbidities

\section{Laboratory findings}

Therapies

Radiological
(CT scan)

findings

respiratory rate $(\mathrm{OR}=$
$2.85,95 \% \mathrm{Cl} 1.28-$
$6.33)$, dizziness $(\mathrm{OR}=$
$2.67,95 \% \mathrm{Cl} 1.18$,
$6.01)$, and increased
systolic blood pressure
(OR: $1.84,95 \% \mathrm{Cl}$
$1.31-2.60)$.

15. Mesas et al., - Mean age of - Indicators of 2020 participants: 40 mortality: Dyspnea (pto 73 years; $\quad \mathrm{OR}=2.5)$ and smoking Malignancy, Pulmonary

Kidney disease, CVD Hypertension, Diabetes, - Of the $\quad(p-O R=1.6)$; disease.

patients, 24.3\% mortality: Headache ( $p$ were non- $\quad O R=0.5)$, cough $(p-$ survivors. $\quad \mathrm{OR}=0.7)$, vomiting $(\mathrm{p}-$ $\mathrm{OR}=0.6)$, diarrhea $(\mathrm{p}-$ $\mathrm{OR}=0.6)$ and fever $(\mathrm{p}-$ $\mathrm{OR}=0.8)$.

16. Izcovich - Total - Prognostic factors - Indicators of mortality: with range of $\quad(\mathrm{OR}=4.39,95 \% \mathrm{Cl} \quad 1.88-3.14), \mathrm{CKD}(\mathrm{OR}=$ 10 to $8910 \quad 2.18-8.81$ ), abdominal $2.27,95 \% \mathrm{Cl} 1.69-3.05$ ), patients per pain $(\mathrm{OR}=1.95,95 \%$ study; Cl 1.36- 1.79), fatigue (OR=285,95\% Cl 2.02

- Increasing $(\mathrm{OR}=1.41,95 \% \mathrm{Cl}$ age identified 1.19-1.68), fever (OR as risk factor of $1.84,95 \% \mathrm{Cl} 1.54$ poor prognosis 2.21) and myalgia or and mortality. arthralgia $(\mathrm{OR}=1.29$ $95 \%$ Cl 1.03- 1.61); - Prognostic factors of mortality: Respiratory failure $(0$ $95 \% \mathrm{Cl} 4.9-91.3)$, low blood pressure $(\mathrm{OR}=$ $6.7,95 \% \mathrm{Cl} 3.14$ 14.33), hypoxemia $(\mathrm{OR}=5.46,95 \% \mathrm{C}$ 2.05- 14.53) $01, .85,95 \% \mathrm{Cl} 2.02-$ Cl 1.77- 2.56), cardiac arrhythmia $(\mathrm{OR}=2.13,95 \%$ Cl.72- 2.65), arterial hypertension $(\mathrm{OR}=2.02$ $95 \% \mathrm{Cl} 1.71-2.38)$ diabetes $(\mathrm{OR}=1.84,95 \%$ Cl 1.61- 2.1), dementia $\mathrm{OR}=1.54,95 \% \mathrm{Cl} 1.31$ 1.81), obesity $(\mathrm{OR}=1.41$ $95 \% \mathrm{Cl} 1.15-1.74)$, cancer 1.55) and dyslipidemia tachycardia $(\mathrm{OR}=2.61$ $95 \% \mathrm{Cl} 1.62-4.22)$, dyspnea $(\mathrm{OR}=3.45$, $95 \% \mathrm{Cl} 2.72-4.38)$, 1.5) $\mathrm{R}=1.26,95 \% \mathrm{Cl} 1.06-$ $\mathrm{OR}=1.35,95 \% \mathrm{Cl} 1.17$

3.51- 24.37), raised $\mathrm{CK}(\mathrm{OR}=2.44,95 \% \mathrm{Cl}$ 1.65- 3.62), high Hs-CRP (OR=14.27, 95\% Cl 5.13- 39.71), high IL-6 (OR=6.68, 95\% Cl 3.20- 13.94), raised $D$-dimer $(O R=6.19,95 \%$ Cl 4.22- 9.08), increased ferritin ( $O R=1.96$, $95 \% \mathrm{Cl} 1.06-3.62)$, high $\mathrm{LDH}(\mathrm{OR}=8.28$, $95 \% \mathrm{Cl} 4.75-14.46)$, elevated PCT (OR=

6.62, $95 \% \mathrm{Cl} 3.32-13.21)$, raised ESR (OR= $4.45,95 \% \mathrm{Cl} 2.56-7.76)$, and $\mathrm{CRP}>8$ (OR= 8.34, 95\% Cl 1.85- 37.62).

- Decreased albumin and lymphocytes, creased CRP, BUN, IL-6, LDH, neutrophil, Ferritin, Cardiac Tnl.

Epidemiological data should be stratified by age, gender and baseline

comorbidities for accurate determination of mortality

predictors.

Severity indicators: High neutrophil count - Severity OR= 5.66, 95\% C1 3.71-8.63), high BNP $\mathrm{OR}=4.99,95 \%$ (l $3.2-7.77)$, $\mathrm{m}$ (BUN $3.1,95 \% \mathrm{Cl} 2.32-4.16)$, high bilirubin (OR= $2.46,95 \% \mathrm{C}$ $2.94,95 \% \mathrm{Cl} 2.18-3.97)$, high IL-6 (OR= $\quad 1.54-3.93)$ and Cl 2.97- 18.27), elevated ESR $(\mathrm{OR}=3.08,95 \% \mathrm{Cl} 2.04-4.65)$

- Mortality indicators: High procalcitonin $\mathrm{OR}=12.42,95 \% \mathrm{Cl} 7.18-21.5)$, myocard injury markers $(O R=10.89,95 \%$ Cl 5.3922.04), high WBC counts $(\mathrm{OR}=4.06,95 \% \mathrm{Cl}$ pleural effusion (OR=3.31,95\% $\mathrm{Cl}$ 2.03- 5.38).

- Risk of severe disease and mortality is higher in elderly patients, with previous comorbidities aised lab biomarkers of inflammation; - Radiological features were no good predictors. 2.7- 6.12), high lactate $(\mathrm{OR}=3.66,95 \% \mathrm{C}$ (2. 11.56), high $\mathrm{D}$-dimer $(\mathrm{OR}=$ 95\% Cl 3.15- 7.34), high $\mathrm{LDH}(\mathrm{OR}=$ .09, 95\% Cl 1.18- 14.17), high CRP (OR= 6.6, 95\% Cl 3.36- 12.99), reduced lymphocyte counts $(\mathrm{OR}=3.57,95 \% \mathrm{Cl} 2$ 6.67), elevated AST (OR= 3.5, 95\% Cl 1.597.71), elevated albumin levels $(\mathrm{OR}=1.53,95 \%$ $\mathrm{Cl} 1.32-1.78)$ and increased creatinine $(\mathrm{OR}=$ $1.14,95 \% \mathrm{Cl} 1.02-1.28)$ 
Demographics Signs and symptoms

Comorbidities

Laboratory findings

Radiological Therapies
(CT scan)

(CT scan)

anorexia $(\mathrm{OR}=2.16$,

$95 \% \mathrm{Cl} 1.14-4.12)$

and tachypnea $(\mathrm{OR}=$

$1.21,95 \% \mathrm{Cl} 1.12-$

NA

et al., 2020 liver disease in

$0 \%$ to $37.6 \%$

Presence

Elevated AST, ALT, tBIL levels.

patients;

- $46.9 \%$

prevalence of at

least one

abnormal LFT

at admission

$56.8,2306$

patients).

18. Hannum - Sample size • Loss of smell-

et al., 2020 ranged from 15 overall prevalence rate

to 7178 .

of $50.2 \%, 95 \% \mathrm{Cl}$

Number of 38.9-61.5; prevalonce

smell loss 2 rate per study: $5-88 \%$

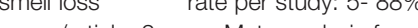

cases/article: 2 o Meta-analysis for

to 4668 pooled prevalence

(prevalence yielded Cochrane's Q=

rate: $5 \%$ to $5784.14, \mathrm{df}=33, \mathrm{p}<$

98.3\%). $\quad 0.001, I^{2}=99.4 \%$.

19. Israfil et al., - Mean age:

$2021 \quad 50.6$ years

symptoms: Common

$\begin{array}{ll}50.6 \text { years } & \text { symptoms: Cough/dry } \\ \text { (range 0.5- } 94 & \text { cough 59.6\% (2146/ } \\ \text { years): } & 3598), \text { fever } 46.9 \%\end{array}$

- Most common:

Hypertension 35.9\%

years);

(3909/10889), diabetes

- Higher

(4342/9242), fatigue

besity $15.95 \%(1735 /$

proportion of

$27.8 \%(1000 / 3598)$

10889), cardiovascular

male patients: dyspnea/shortness of disease 13.92\% (1516/

$60.3 \%$ (6567) breath $20.23 \%(728 /$ 10889), asthma $4.42 \%$

female: $39.7 \%$ myalga $12.64 \%(455 /$

(481/10889), COPD 4.31

- Most common: lymphocytopenia 55.9\%

- Most

(4177/7470);

common

- Other major findings: Elevated levels of

abnormality:

CRP 61.9\% (830/1340), AST 53.3\% (3481/ Bilateral lungs

6537), ALT 35.64\% (2318/6503), LDH 40.8\% 71.1\% (1581/

(392/973), ESR 72.99\% (173/237), serum 2223);

ferritin 63\% (62/99), (IL-6) 52\% (51/99),

- Other major

prothrombin time $35.47 \%(102 / 286)$ and D- findings: GGO

$48 \%$ (432/900)

(4322/10889); 3598), diarrhea $11.95 \%$ malignancy $3.99 \%$ (435

- Ethnic (430/3598), headache 10889).

origin: Asian, $\quad$ 10.8\% (389/3598),

European and anorexia 9.9\% (356/

North

3598),

American;

$3598)$, sore throat

- Smokers expectoration $7.48 \%$

consolidation

$21.88 \%(140$

$640)$, pleural

effusion $20.6 \%$

(195/947), lung

lesions $78.3 \%$

(180/230),

enlarged lymph

- Abnormal LFT

findings were

considered as

hallmark of COVID

19, with

association with

disease severity

and in-hospita

mortality.

Longitudinal

assessments of

chemosensory

function would be

useful to identify

patients with

continued

impairment who

might require

further treatment

and olfactory

training.

- Laboratory

investigations and

CT scan reports

with clinical

correlation can

provide useful

information to

nable correct

diagnosis and

etter managemen

of COVID-19

patients. 
Demographics Signs and symptoms

Comorbidities

Laboratory findings

Radiological Therapies
(CT scan)

(CT scan)

findings

(active): about (269/3598), upper

$14.2 \%(641 / \quad$ airway congestion

4530); $\quad 6.67 \%(240 / 3598)$ and

- Severe rhinitis $5.86 \%(211$

patients: $37.4 \%$ 3598);

nodes $50.7 \%$

(153/302),

(2408/6446). - Asymptomatic

thickened

bronchial walls

thickened lung

thickened lung

$(62 / 73)$ and

thickened

interlobular

septa $47.1 \%$

20.

$\begin{array}{lll}\text { Poly et al., } & \text { - Total } & \text { - Obesity significantly } \\ 2021 & \text { sample size of } & \text { associated with an } \\ \text { studies } & \text { increased risk of } \\ \text { analyzed } & \text { mortality (p-RR 1.42, } \\ \text { ranged from } 58 & 95 \% \mathrm{Cl} 1.24-1.63, \mathrm{p}< \\ \text { to } 177133 ; & 0.001) ; \\ \text { males: } 43.3 \% & \begin{array}{l}\text { - Class III obesity } \\ \text { to } 80.2 \% ;\end{array} & \text { patients observed a } \\ \text { Mean/median } & \text { greater risk (p-RR= } \\ \text { age: } 49.1 \text { to } 76 & 1.92,95 \% \mathrm{Cl} 1.50- \\ \text { years. } & 2.47, \mathrm{p}<0.001, \mathrm{I}^{2}= \\ & & 31.99) .\end{array}$

Risk of mortality

NA

(80/170).

\section{ssessment in obese}

COVID-19 patients:

Diabetes $(\mathrm{p}-\mathrm{RR}=1.19$

$(95 \% \mathrm{Cl} 1.07-1.32, \mathrm{p}=$

$0.001)$, stroke $(p-R R=1.80$

(95\% $\mathrm{Cl} 0.89-3.64, \mathrm{p}=$

$0.10)$, hypertension $(\mathrm{p}-\mathrm{RR}=$

$1.07,95 \% \mathrm{Cl} 0.92-1.25$

$\mathrm{p}=0.35)$, CKD $(\mathrm{p}-\mathrm{RR}=$

$1.57,95 \% \mathrm{Cl} 1.57-1.91$

$p<0.001)$, COPD ( $p-R R=$

$1.34,95 \% \mathrm{Cl} 1.18-1.52$

NA

NA

- Obesity is a risk factor for mortality in COVID-19;

- Clinicians must

quickly start

medical

interventions in

obese COVID-19

patients;

- Further

investigations

would urgently be

required to

understand the

pathophysiological

association

between obesity

and risk of COVID-

19 related

mortality.

NA- Data under the respective heading was either not analyzed or not reported for the entire number of patients in the respective article. ALT, alanine aminotransferase; AST, aspartate aminotransferase; BMI, body mass index; BNP, B-type natriuretic peptide; $B U N$, blood urea nitrogen; $C B C$, complete blood count; Cl, confidence interval; $C K$, creatine kinase; CKD, chronic kidney disease; CK-MB, creatine kinase, myocardial band, an isoenzyme of creatine kinase; COPD, chronic obstructive pulmonary disease; COVID-19, coronavirus disease 2019; CRP, C-reactive protein; CT, computed tomography; CVD, cardiovascular disease; df, degree of freedom; ECMO, extracorporeal membrane oxygenation; ESR, erythrocyte sedimentation rate; GGO, ground glass opacity; ICU, intensive care unit; IL (interleukin); KFT, kidney function test; LDH, lactate dehydrogenase; LFT, liver function test; MERS, middle east respiratory syndrome; NT-proBNP, Nterminal pro-BNP; OR, odds ratio; PCT, procalcitonin; $p-O R$, pooled odds ratio; $p$-RR, pooled relative risk; $P S Q l$, Pittsburgh sleep quality index; RBC, red blood cell; RDW, RBC distribution width; RDW-CV, RBC distribution width- coefficient of variation; RR, relative risk; SARS, severe acute respiratory syndrome; SCr, serum creatinine; Tnl, troponin I; WBC, white blood cell. 
TABLE 2 | Putative independent predictors of COVID-19 adverse prognosis, severity or mortality.

\begin{tabular}{|c|c|c|c|c|c|}
\hline $\begin{array}{l}\text { S. } \\
\text { No. }\end{array}$ & Biomarkers & $\begin{array}{c}\text { Article } \\
\text { reference }\end{array}$ & Clinical outcome & $\begin{array}{c}\text { Number of } \\
\text { patients }\end{array}$ & Severity or Fatality estimate \\
\hline
\end{tabular}

PARAMETERS OF LIVER FUNCTION

1. Elevated AST

Del Zompo et al., Severe COVID-19 2020

$\begin{array}{ll}\text { In-hospital fatality } \\ \text { Moutchia et al., } & \text { Severe/critical COVID-19 }\end{array}$
2020

Jutzeler et al., $\quad$ Severe COVID-19

2020

Zhang JJY. et al., ICU admission

2020

Li et al., 2021

Izcovich et al., 2020

2. Elevated ALT 2020

Moutchia et al., 2020

Zhang JJY. et al., 2020

3. Increased tBIL

Del Zompo et al., $\quad$ Severe COVID-19 2020

Izcovich et al.,

2020

4. Decreased albumin

Jutzeler et al., 2020

Lu et al., 2020 Izcovich et al., 2020

\section{PARAMETERS OF KIDNEY FUNCTION}

5. Elevated SCr

6. Higher BUN

Shao et al., 2020

Moutchia et al., 2020

Izcovich et al., 2020

Li et al., 2021

Shao et al., 2020

Lu et al., 2020

Izcovich et al.,

2020

Elevated blood urea Moutchia et al., 2020

\section{HAEMATOLOGICAL PARAMETERS}

7. Absolute RDW-CV

8. Low hemoglobin

9. Low platelet count

10. Low lymphocyte count
Jutzeler et al., $\quad$ Severe COVID-19

2020

Jutzeler et al.,

2020

Lu et al., 2020

Li et al., 2021

Izcovich et al.,

2020

Henry et al., 2020 Severe COVID-19

In-hospital fatality

Severe COVID-19

Fatality

ICU admission

Fatality
Lippi et al., 2020 Severe COVID-19
6263

2395

2705

184

2153

$479^{*}$

9179

2969

6249

2613

2540

2153

5153

2086

5098

131

110

615

1266

336

1968

2138

2019

1116

1508

$479^{*}$

1445

1458

424

3890

624

2,654

342

357

615

$479^{*}$

3676

1140

800

$198^{\$}$

Severe COVID-19
$\mathrm{OR}=3.17,95 \% \mathrm{Cl} 2.10-4.77$

$\mathrm{OR}=4.39,95 \% \mathrm{Cl} 2.68-7.18$

$\mathrm{MPR}=2.14,95 \% \mathrm{Cl} 1.80-2.54$

SMD: $0.85,95 \%$ Cl 0.61-1.09

$p=0.0040$

$\mathrm{OR}=3.26,95 \% \mathrm{Cl} 2.40-4.42, \mathrm{p}<0.001, \mathrm{l}^{2}=5.3 \%$

$\mathrm{OR}=3.41,95 \% \mathrm{Cl} 2.7-4.3$

$\mathrm{OR}=3.5,95 \% \mathrm{Cl} 1.59-7.71$

$\mathrm{OR}=1.54,95 \% \mathrm{Cl} 1.17-2.03$

$\mathrm{OR}=1.48,95 \% \mathrm{Cl} 1.12-1.96$

$\mathrm{MPR}=1.59,95 \% \mathrm{Cl} 1.36-1.87$

$p=0.024$

$\mathrm{OR}=2.32,95 \% \mathrm{Cl} 1.18-4.58$

$\mathrm{OR}=7.75,95 \% \mathrm{Cl} 2.28-26.40$

$\mathrm{OR}=2.94,95 \% \mathrm{Cl} 2.18-3.97$

$\mathrm{SMD}=-1.60,95 \% \mathrm{Cl}-2.97-(-0.24)$

$\mathrm{SMD}=-1.14,95 \% \mathrm{Cl}-1.41-(-0.85)$

$\mathrm{OR}=0.11,95 \% \mathrm{Cl} 0.06-0.19$

$\mathrm{OR}=1.11,95 \% \mathrm{Cl} 1.01-1.21$

$\mathrm{OR}=1.53,95 \% \mathrm{Cl} 1.32-1.78$

$\mathrm{MD}=7.78 \mu \mathrm{mol} / \mathrm{l}, 95 \% \mathrm{Cl}$ 4.43-11.14

$\mathrm{MD}=20.19 \mu \mathrm{mol} / \mathrm{l}, 95 \% \mathrm{Cl} 14.96-25.42$

$\mathrm{MPR}=1.90,95 \% \mathrm{Cl} 1.07-3.36$

$\mathrm{OR}=1.89,95 \% \mathrm{Cl} 0.87-4.10$

$\mathrm{OR}=1.14,95 \% \mathrm{Cl} 1.02-1.28$

$\mathrm{OR}=2.14,95 \% \mathrm{Cl} 1.14-4.01, \mathrm{p}=0.018, \mathrm{I}^{2}=0.0 \%$

$\mathrm{MD}=2.12 \mu \mathrm{mol} / \mathrm{l}, 95 \% \mathrm{Cl} 1.74-2.50$

$\mathrm{MD}=4.07 \mu \mathrm{mol} / \mathrm{l}, 95 \% \mathrm{Cl} 3.33-4.81$

$\mathrm{OR}=8.49,95 \% \mathrm{Cl} 5.81-12.40$

$\mathrm{OR}=3.66,95 \% \mathrm{Cl} 2.82-4.74$

$\mathrm{MPR}=3.63,95 \% \mathrm{Cl} 1.73-7.65$

Fold increase: $1.05,95 \% \mathrm{Cl} 1.03$ - 1.08-fold

$\mathrm{SMD}=-0.23,95 \% \mathrm{Cl}-0.41-(-0.06)$

$\mathrm{SMD}=-0.57,95 \% \mathrm{Cl}-0.68-(-0.45)$

$\mathrm{OR}=0.33,95 \% \mathrm{Cl} 0.24-0.44$

$\mathrm{OR}=2.82,95 \% \mathrm{Cl} 2.07-3.83, \mathrm{p}<0.001, \mathrm{I}^{2}=0.0 \%$

$\mathrm{OR}=5.43,95 \% \mathrm{Cl} 2.55-11.56$

$\mathrm{OR}=4.20,95 \% \mathrm{Cl} 3.46-5.09$

$\mathrm{OR}=3.71,95 \% \mathrm{Cl} 1.63-8.44$

Severe lymphopenia

$(<0.5 \times 10 \times 9 /)$ had 12 -fold increased odds of inhospital mortality. 
TABLE 2 | Continued

\begin{tabular}{|c|c|c|c|c|c|}
\hline $\begin{array}{l}\text { S. } \\
\text { No. }\end{array}$ & Biomarkers & $\begin{array}{l}\text { Article } \\
\text { reference }\end{array}$ & Clinical outcome & $\begin{array}{l}\text { Number of } \\
\text { patients }\end{array}$ & Severity or Fatality estimate \\
\hline & & $\begin{array}{l}\text { Mudatsir et al., } \\
2020\end{array}$ & & & \\
\hline & & $\begin{array}{l}\text { Moutchia et al., } \\
2020\end{array}$ & Severe COVID-19 & 3875 & $\mathrm{MPR}=1.74,95 \% \mathrm{Cl} 1.43,2.12$ \\
\hline & & $\begin{array}{l}\text { Jutzeler et al., } \\
2020\end{array}$ & Fatality & 255 & $\mathrm{SMD}=-0.92,95 \% \mathrm{Cl}-1.3-(-0.55)$ \\
\hline & & Li et al., 2021 & ICU admission & $479^{*}$ & $\mathrm{OR}=4.60,95 \% \mathrm{Cl} 3.25-6.51, \mathrm{p}<0.001, \mathrm{I}^{2}=0.0 \%$ \\
\hline & & Lu et al., 2020 & Fatality & 615 & $\mathrm{OR}=0.21,95 \% \mathrm{Cl} 0.12-0.38$ \\
\hline & & Izcovich et al., & Severe COVID-19 & 1909 & $\mathrm{OR}=2.28,95 \% \mathrm{Cl} 1.21-4.30$ \\
\hline & & 2020 & Fatality & 544 & $\mathrm{OR}=3.57,95 \% \mathrm{Cl} 2-6.67$ \\
\hline \multirow[t]{5}{*}{11.} & Increased neutrophil count & Henry et al., 2020 & Severe COVID-19 & 313 & $\mathrm{OR}=7.99,95 \% \mathrm{Cl} 1.77-36.14$ \\
\hline & & & Fatality & 183 & $\mathrm{OR}=7.87,95 \% \mathrm{Cl} 1.75-35.35$ \\
\hline & & $\begin{array}{l}\text { Moutchia et al., } \\
2020\end{array}$ & Severe COVID-19 & 1237 & $\begin{array}{l}\text { Severe COVID-19 with higher likelihood } \\
\mathrm{MPR}=4.29,95 \% \mathrm{Cl} 1.74-10.64\end{array}$ \\
\hline & & Lu et al., 2020 & Fatality & 274 & $\mathrm{OR}=17.56,95 \% \mathrm{Cl} 10.67-28.90$ \\
\hline & & $\begin{array}{l}\text { Izcovich et al., } \\
2020\end{array}$ & Severe COVID-19 & 4945 & $\mathrm{OR}=5.66,95 \% \mathrm{Cl} 3.71-8.63$ \\
\hline \multirow[t]{8}{*}{12.} & Increased leukocyte count & $\begin{array}{l}\text { Moutchia et al., } \\
2020\end{array}$ & Severe COVID-19 & 3455 & $\begin{array}{l}\text { Severe COVID-19 with higher likelihood } \\
\mathrm{MPR}=3.95,95 \% \mathrm{Cl} 2.35-6.65\end{array}$ \\
\hline & & $\begin{array}{l}\text { Jutzeler et al., } \\
2020\end{array}$ & Fatality & 277 & $\mathrm{SMD}=2.21,95 \% \mathrm{Cl} 0.61-3.64$ \\
\hline & & Lu et al., 2020 & Fatality & 615 & $\mathrm{OR}=9.13,95 \% \mathrm{Cl} 5.71-14.59$ \\
\hline & & Zhang JJY. et al., & ICU admission & 2153 & $p<0.0001$ \\
\hline & & 2020 & Fatality & & $p=0.0005$ \\
\hline & & Izcovich et al., & Severe COVID-19 & 9331 & $\mathrm{OR}=4.67,95 \% \mathrm{Cl} 3.17-6.88$ \\
\hline & & 2020 & Fatality & 2870 & $\mathrm{OR}=4.06,95 \% \mathrm{Cl} 2.7-6.12$ \\
\hline & & $\begin{array}{l}\text { Mudatsir et al., } \\
2020\end{array}$ & Severe COVID-19 & $102^{\$}$ & $\mathrm{OR}=5.38,95 \% \mathrm{Cl} 3.36-8.62$ \\
\hline \multicolumn{6}{|c|}{ PARAMETERS OF INFLAMMATION/INFECTION } \\
\hline \multirow[t]{6}{*}{13.} & Elevated CRP & $\begin{array}{l}\text { Moutchia et al., } \\
2020\end{array}$ & Severe/critical COVID-19 & 2740 & $\mathrm{MPR}=1.60,95 \% \mathrm{Cl} 1.32-1.93$ \\
\hline & & $\begin{array}{l}\text { Jutzeler et al., } \\
2020\end{array}$ & Severe COVID-19 & 277 & $\mathrm{SMD}=1.47,95 \% \mathrm{Cl} 0.88-2.07$ \\
\hline & & Lu et al., 2020 & Fatality & 424 & $\mathrm{OR}=12.11,95 \% \mathrm{Cl} 5.24-27.98$ \\
\hline & & Izcovich et al., & Severe COVID-19 & 9094 & $\mathrm{OR}=4.5,95 \% \mathrm{Cl} 3.1-6.23$ \\
\hline & & 2020 & Fatality & 2107 & $\mathrm{OR}=6.6,95 \% \mathrm{Cl} 3.36-12.99$ \\
\hline & & Li et al., 2021 & ICU admission & $479^{*}$ & $\mathrm{OR}=4.02,95 \% \mathrm{Cl} 2.80-5.79, \mathrm{p} \leq 0.001, \mathrm{I}^{2}=11.1 \%$ \\
\hline 14. & Higher ESR & $\begin{array}{l}\text { Moutchia et al., } \\
2020\end{array}$ & Severe/critical COVID-19 & 545 & $\mathrm{MPR}=1.67,95 \% \mathrm{Cl} 0.67-4.17$ \\
\hline \multirow[t]{2}{*}{15.} & Increased IL-6 & $\begin{array}{l}\text { Jutzeler et al., } \\
2020\end{array}$ & Fatality & 110 & $\mathrm{SMD}=1.21,95 \% \mathrm{Cl} 0.93-1.5$ \\
\hline & & $\begin{array}{l}\text { Izcovich et al., } \\
2020\end{array}$ & Severe COVID-19 & 1211 & $\mathrm{OR}=7.36,95 \% \mathrm{Cl} 2.97-18.27$ \\
\hline \multirow[t]{3}{*}{16.} & Elevated PCT & $\begin{array}{l}\text { Zhang JJY. et al., } \\
2020\end{array}$ & ICU admission & 2153 & $p<0.0001$ \\
\hline & & Li et al., 2021 & ICU admission & $479^{*}$ & $\begin{array}{l}\mathrm{OR}=6.69,95 \% \mathrm{Cl} 3.99-11.20, \mathrm{p} \leq 0.001, \mathrm{I}^{2}= \\
13.6 \%\end{array}$ \\
\hline & & $\begin{array}{l}\text { Izcovich et al., } \\
2020\end{array}$ & Fatality & 4735 & $\mathrm{OR}=12.42,95 \% \mathrm{Cl} 7.18-21.5$ \\
\hline \multicolumn{6}{|c|}{ OTHER BIOCHEMICAL PARAMETER } \\
\hline 17. & Elevated serum ferritin & $\begin{array}{l}\text { Moutchia et al., } \\
2020\end{array}$ & Severe/critical COVID-19 & 412 & $\mathrm{MPR}=2.3,95 \% \mathrm{Cl} 1.67-3.17$ \\
\hline \multicolumn{6}{|c|}{ COAGULATION PARAMETER } \\
\hline \multirow[t]{5}{*}{18.} & Elevated D-dimer & $\begin{array}{l}\text { Moutchia et al., } \\
2020\end{array}$ & Severe/critical COVID-19 & 2030 & $\mathrm{MPR}=2.27,95 \% \mathrm{Cl} 1.67-3.09$ \\
\hline & & $\begin{array}{l}\text { Figliozzi et al., } \\
2020\end{array}$ & $\begin{array}{l}\text { Combined adverse outcome (ICU } \\
\text { admission or IMV or fatality) }\end{array}$ & 3270 & $\mathrm{OR}=4.39,95 \% \mathrm{Cl} 1.85-10.41, \mathrm{p}=0.003$ \\
\hline & & & Fatality & & $\mathrm{OR}=4.40,95 \% \mathrm{Cl} 1.10-17.58, \mathrm{p}=0.04$ \\
\hline & & Izcovich et al., & Severe COVID-19 & 6356 & $\mathrm{OR}=3.27,95 \% \mathrm{Cl} 2.46-4.36$ \\
\hline & & 2020 & Fatality & 4361 & $\mathrm{OR}=4.81,95 \% \mathrm{Cl} 3.15-7.34$ \\
\hline 19. & Prolonged PT & $\begin{array}{l}\text { Jutzeler et al., } \\
2020\end{array}$ & Fatality & 206 & $\mathrm{SMD}=7.99,95 \% \mathrm{Cl} 4.64-11.34$ \\
\hline
\end{tabular}

(Continued) 
TABLE 2 | Continued

\begin{tabular}{|c|c|c|c|c|c|}
\hline $\begin{array}{l}\text { S. } \\
\text { No. }\end{array}$ & Biomarkers & $\begin{array}{l}\text { Article } \\
\text { reference }\end{array}$ & Clinical outcome & $\begin{array}{l}\text { Number of } \\
\text { patients }\end{array}$ & Severity or Fatality estimate \\
\hline \multicolumn{6}{|c|}{ MARKER OF TISSUE DAMAGE } \\
\hline \multirow[t]{8}{*}{20.} & Elevated LDH & $\begin{array}{l}\text { Moutchia et al., } \\
2020\end{array}$ & Severe/critical COVID-19 & 1893 & $\mathrm{MPR}=2.41,95 \% \mathrm{Cl} 1.65-3.51$ \\
\hline & & $\begin{array}{l}\text { Jutzeler et al., } \\
2020\end{array}$ & Severe COVID-19 & 93 & $\mathrm{SMD}=1.71,95 \% \mathrm{Cl} 1.08-2.34$ \\
\hline & & Lu et al., 2020 & Fatality & 465 & $\mathrm{OR}=37.52,95 \% \mathrm{Cl} 24.68-57.03$ \\
\hline & & Zhang JJY. et al., & ICU admission & 2153 & $p<0.0001$ \\
\hline & & 2020 & ARDS & & $p<0.0001$ \\
\hline & & & Fatality & & $\mathrm{p}<0.0001$ \\
\hline & & Izcovich et al., & Severe COVID-19 & 7955 & $\mathrm{OR}=4.48,95 \% \mathrm{Cl} 3.21-6.25$ \\
\hline & & 2020 & Fatality & 1440 & $\mathrm{OR}=4.09,95 \% \mathrm{Cl} 1.18-14.17$ \\
\hline \multicolumn{6}{|c|}{ PARAMETERS OF CARDIAC INJURY } \\
\hline \multirow[t]{3}{*}{21.} & Increased Tnl or & Izcovich et al., & Severe COVID-19 & 3627 & $\mathrm{OR}=10,95 \% \mathrm{Cl} 6.84-14.62$ \\
\hline & myocardial injury & 2020 & Fatality & 3855 & $\mathrm{OR}=10.89,95 \% \mathrm{Cl} 5.39-22.04$ \\
\hline & Elevated Tnl or TnT & Li et al., 2020 & Fatality & 1028 & $\begin{array}{l}\mathrm{RR}=4.69,95 \% \mathrm{Cl} 3.39-6.48, \mathrm{p}<0.001, \mathrm{I}^{2}= \\
22.5 \%\end{array}$ \\
\hline 22. & Elevated CK & Li et al., 2020 & Severe COVID-19 & 2174 & $R R=1.98,95 \% \mathrm{Cl} 1.50-2.61, p<0.001, I^{2}=0.0 \%$ \\
\hline
\end{tabular}

NA- The parameter value was not applicable or not mentioned or could not be ascertained with the given information. *- The number of patients as mentioned for ICU COVID-19 cases in

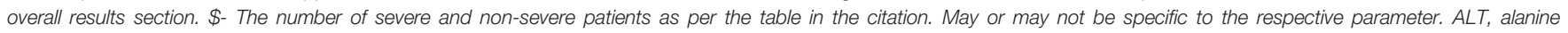
aminotransferase; ARDS, acute respiratory distress syndrome; $A S T$, aspartate aminotransferase; BUN, blood urea nitrogen; CRP, C-reactive protein; CK, creatine kinase; ESR, erythrocyte

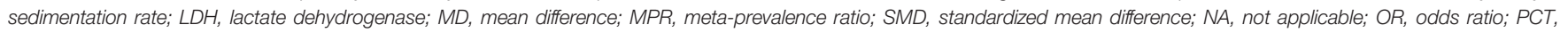
procalcitonin; PT, prothrombin time; RDW-CV, red blood cell distribution width-coefficient of variation; RR, relative risk; SCr, serum creatinine; tBIL, total bilirubin; Tnl, troponin I; TnT, troponin $T$.

et al., 2020; Jin et al., 2020; Tao et al., 2020). The systematic review and meta-analysis conducted by Jutzeler et al. identified abnormal CT scans in nearly $90 \%$ ( $89.6 \%$ specifically) of the COVID-19 confirmed adult patients, $88.6 \%$ of the pregnant patients and $65 \%$ of the pediatric and neonatal patients (Jutzeler et al., 2020). The major finding in CT imaging was the occurrence of unilateral or bilateral pneumonia in $83.6 \%$ (6620/7917) adult patients, $88.6 \%(31 / 35)$ pregnant and $65 \%$ (194/298) pediatric and neonatal COVID-19 cases (Jutzeler et al., 2020). Other prominent abnormal CT features included air bronchogram $(50.5 \%, 264 / 523)$ and ground-glass opacity (GGO) with consolidation $(47.4 \%, 153 / 323)$ and without $(43.8 \%, 2446 / 5591)$ in adult patients, GGO $(85.3 \%, 29 / 34)$ and consolidation $(50 \%, 8 / 16)$ in pregnant patients, and GGO $(38.9 \%, 108 / 278)$ and local patchy shadowing $(23.3 \%, 52 / 223)$ in pediatric and neonatal patients (Jutzeler et al., 2020).

\section{CONCLUSIONS}

Identification of high-risk clinical and laboratory features contribute to early prediction, diagnosis and efficient treatment of patients ( $\mathrm{Li}$ et al., 2021). A fatality rate of $7.7 \%$ with about $8 \%$ of the COVID-19 patients being asymptomatic was observed during the early pandemic period (Jutzeler et al., 2020). Since, it is difficult to record the exact number of asymptomatic cases, owing to obvious reasons (like no hospital/clinic visit, hence no medical record; or lack of awareness that a potentially fatal disease can be asymptomatic in some patients) such value is deemed to be 6- to 10-fold higher (Jutzeler et al., 2020). Hence, more aggressive antigen detection, as well as serological surveillance of contacts of confirmed COVID-19 patients, is necessary to enable screening and identification of asymptomatic COVID-19 patients. Further, prospective well-planned cohort studies would be necessary to enable further characterization of the overall, genderspecific and/or geographical location-based risk factors.

It is imperative to categorize COVID-19 patients based on their comorbidities, like impaired kidney or liver functions or cardiac injury, etc. As discussed in the present work, AKI is a critical complication of COVID-19 and calls for immediate care and monitoring (Shao et al., 2020) to minimize the risk of severity and poor prognosis. Similarly, abnormal LFTs are important early predictors of COVID-19 severity and in-hospital mortality (Del Zompo et al., 2020). Also, pre-existing chronic liver disease, especially cirrhosis, is an indicator of a high risk of mortality. Hence, aggressive interventions for such cases must be exercised. This would enable better patient management and may improve the disease outcome. Measurement of anthropometric parameters, especially BMI, is also recommended for COVID-19 patient management, importantly for patients who are or above 65 years of age (Földi et al., 2020; Poly et al., 2021). Basic hematological screening that can be done with minimal resources can be a lifesaver. The findings that lymphopenia and neutrophilia at the time of hospital admission indicate poor COVID-19 outcome call for routine hematological monitoring. It would enable an early careful intervention in such patients enabling better patient care. Such regular monitoring may also aid in the stratification and the management of risk associated with COVID-19 (Henry et al., 2020). Further, it is also important to stratify epidemiological data based on demographic characteristics and risk factors for adverse COVID-19 outcomes, to enable exact and aggressive patient care (Mesas et al., 2020). Based on the analysis in this work, we can conclude that careful monitoring of clinical data, risk factors and disease 
biomarkers (Israfil et al., 2021) may enable early determination of COVID-19-led severity. Such an early estimate would be helpful in efficient patient management and possibly minimize the related mortality.

\section{AUTHOR CONTRIBUTIONS}

JS conceptualized the study, retrieved the articles, analyzed the data and guided inclusion of specific information, drafted and proof-read the manuscript. RR reviewed the data, analyzed the information, tabulated findings, drafted and proof-read the manuscript. MB helped in information retrieval and inclusion of findings. PA provided intellectual inputs and proof-read the

\section{REFERENCES}

Coronavirus Could Cost the Global Economy Trillions on a Sars Baseline. Available at: https://www.ccn.com/coronavirus-could-cost-the-global-economytrillions-on-a-sars-baseline/.

Cheng, Y., Luo, R., Wang, K., Zhang, M., Wang, Z., Dong, L., et al. (2020). Kidney Disease Is Associated With in-Hospital Death of Patients With COVID-19. Kidney Int. 97 (5), 829-838. doi: 10.1016/j.kint.2020.03.005

Chen, N., Zhou, M., Dong, X., Qu, J., Gong, F., Han, Y., et al. (2020). Epidemiological and Clinical Characteristics of 99 Cases of 2019 Novel Coronavirus Pneumonia in Wuhan, China: A Descriptive Study. Lancet 395 (10223), 507-513. doi: 10.1016/s0140-6736(20)30211-30217

Chung, M., Bernheim, A., Mei, X., Zhang, N., Huang, M., Zeng, X., et al. (2020). CT Imaging Features of 2019 Novel Coronavirus, (2019-Ncov). Radiology 295 (1), 202-207. doi: 10.1148/radiol.2020200230

Del Zompo, F., De Siena, M., Ianiro, G., Gasbarrini, A., Pompili, M., and Ponziani, F. R. (2020). Prevalence of Liver Injury and Correlation With Clinical Outcomes in Patients With COVID-19: Systematic Review With Meta-Analysis. Eur. Rev. Med. Pharmacol. Sci. 24 (24), 13072-13088. doi: 10.26355/eurrev_202012_24215

Emem, M. (2020) Multi-Billion Dollar Coronavirus Vaccine Deal Could Save the Economy. CCN Headlines Opinion. Available at: https://www.ccn.com/ coronavirus-could-cost-the-global-economy-trillions-on-a-sars-baseline/.

Ferrando, M., Bagnasco, D., Roustan, V., Canonica, G. W., Braido, F., and Baiardini, I. (2016). Sleep Complaints and Sleep Breathing Disorders in Upper and Lower Obstructive Lung Diseases. J. Thorac. Dis. 8 (8), E716E725. doi: 10.21037/jtd.2016.07.82

Figliozzi, S., Masci, P. G., Ahmadi, N., Tondi, L., Koutli, E., Aimo, A., et al. (2020). Predictors of Adverse Prognosis in COVID-19: A Systematic Review and MetaAnalysis. Eur. J. Clin. Invest. 50 (10), e13362. doi: 10.1111/eci.13362

Földi, M., Farkas, N., Kiss, S., Zádori, N., Váncsa, S., Szakó, L., et al. (2020). Obesity Is a Risk Factor for Developing Critical Condition in COVID-19 Patients: A Systematic Review and Meta-Analysis. Obes. Rev. 21 (10), e13095. doi: 10.1111/ obr.13095

Ghahramani, S., Tabrizi, R., Lankarani, K. B., Kashani, S. M. A., Rezaei, S., Zeidi, N., et al. (2020). Laboratory Features of Severe vs. non-Severe COVID-19 Patients in Asian Populations: A Systematic Review and Meta-Analysis. Eur. J. Med. Res. 25 (1), 30. doi: 10.1186/s40001-020-00432-3

Gu, X., Li, X., An, X., Yang, S., Wu, S., Yang, X., et al. (2020). Elevated Serum Aspartate Aminotransferase Level Identifies Patients With Coronavirus Disease 2019 and Predicts the Length of Hospital Stay. J. Clin. Lab. Anal. 34, e23391. doi: 10.1002/jcla.23391

Hannum, M. E., Ramirez, V. A., Lipson, S. J., Herriman, R. D., Toskala, A. K., Lin, C., et al. (2020). Objective Sensory Testing Methods Reveal a Higher Prevalence of Olfactory Loss in COVID-19 Positive Patients Compared to Subjective Methods: A Systematic Review and Meta-Analysis. Chem. Senses. 45 (9), 865-874. doi: 10.1093/chemse/bjaa064

Henry, B., Cheruiyot, I., Vikse, J., Mutua, V., Kipkorir, V., Benoit, J., et al. (2020). Lymphopenia and Neutrophilia at Admission Predicts Severity and Mortality manuscript. VS conceived the study, provided intellectual inputs, guided the inclusion of information, proof-read and approved the final version of the manuscript. All authors contributed to the article and approved the submitted version.

\section{FUNDING}

IS received institutional support from AIIMS, Bathinda, Punjab, India. RR is presently an independent research fellow (Research Associate) of the Council of Scientific and Industrial Research (CSIR), Government of India. VS received financial support (Faculty Recharge Programme) from the University Grants Commission (UGC), Govt. of India. in Patients With COVID-19: A Meta-Analysis. Acta BioMed. 91 (3), e2020008. doi: 10.23750/abm.v91i3.10217

Huang, C., Wang, Y., Li, X., Ren, L., Zhao, J., Hu, Y., et al. (2020). Clinical Features of Patients Infected With 2019 Novel Coronavirus in Wuhan, China. Lancet 395, 497-506. doi: 10.1016/S0140-6736(20)30183-5

Israfil, S. M. H., Sarker, M. M. R., Rashid, P. T., Talukder, A. A., Kawsar, K. A., Khan, F., et al. (2021). Clinical Characteristics and Diagnostic Challenges of COVID-19: An Update From the Global Perspective. Front. Public Health 8, 567395. doi: 10.3389/fpubh.2020.567395

Izcovich, A., Ragusa, M. A., Tortosa, F., Lavena Marzio, M. A., Agnoletti, C., Bengolea, A., et al. (2020). Prognostic Factors for Severity and Mortality in Patients Infected With COVID-19: A Systematic Review. PloS One 15 (11), e0241955. doi: 10.1371/journal.pone.0241955

Jahrami, H., BaHammam, A. S., Bragazzi, N. L., Saif, Z., Faris, M., and Vitiello, M. V. (2021). Sleep Problems During the COVID-19 Pandemic by Population: A Systematic Review and Meta-Analysis. J. Clin. Sleep Med. 17 (2), 299-313. doi: $10.5664 /$ jcsm. 8930

Jin, Y.-H., Cai, L., Cheng, Z.-S., Cheng, H., Deng, T., Fan, Y.-P., et al. (2020). A Rapid Advice Guideline for the Diagnosis and Treatment of 2019 Novel Coronaviru-Ncov) Infected Pneumonia (Standard Version). Mil. Med. Res. 7 (1), 4. doi: 10.1186/s40779-020-0233-6

Jutzeler, C. R., Bourguignon, L., Weis, C. V., Tong, B., Wong, C., Rieck, B., et al. (2020). Comorbidities, Clinical Signs and Symptoms, Laboratory Findings, Imaging Features, Treatment Strategies, and Outcomes in Adult and Pediatric Patients With COVID-19: A Systematic Review and Meta-Analysis. Travel Med. Infect. Dis. 37, 101825. doi: 10.1016/j.tmaid.2020.101825

Li, J., He, X., Yuan, Y., Zhang, W., Li, X., Zhang, Y., et al. (2021). Meta-Analysis Investigating the Relationship Between Clinical Features, Outcomes, and Severity of Severe Acute Respiratory Syndrome Coronavirus 2 (SARS-Cov-2) Pneumonia. Am. J. Infect. Control 49 (1), 82-89. doi: 10.1016/j.ajic.2020.06.008 Li, X., Pan, X., Li, Y., An, N., Xing, Y., Yang, F., et al. (2020). Cardiac Injury Associated With Severe Disease or ICU Admission and Death in Hospitalized Patients With COVID-19: A Meta-Analysis and Systematic Review. Crit. Care 24, 468. doi: 10.1186/s13054-020-03183-Z

Lippi, G., Henry, B. M., and Sanchis-Gomar, F. (2020). Red Blood Cell Distribution Is a Significant Predictor of Severe Illness in Coronavirus Disease 2019. Acta Haematol. 25, 1-5. doi: 10.1159/000510914

Loomba, R. S., Aggarwal, G., Aggarwal, S., Flores, S., Villarreal, E. G., Farias, J. S., et al. (2021). Disparities in Case Frequency and Mortality of Coronavirus Disease 2019 (COVID-19) Among Various States in the United States. Ann. Med. 53 (1), 151-159. doi: 10.1080/07853890.2020.1840620

Lu, L., Zhong, W., Bian, Z., Li, Z., Zhang, K., Liang, B., et al. (2020). A Comparison of Mortality-Related Risk Factors of COVID-19, SARS, and MERS: A Systematic Review and Meta-Analysis. J. Infect. 81 (4), e18-e25. doi: 10.1016/j.jinf.2020.07.002

Malaiyan, J., Arumugam, S., Mohan, K., and Radhakrishnan, G. (2021). An Update on the Origin of SARS-Cov-2: Despite Closest Identity, Bat (Ratg13) and Pangolin Derived Coronaviruses Varied in the Critical Binding Site and OLinked Glycan Residues. J. Med. Virol. 93 (1), 499-505. doi: 10.1002/jmv.26261 
Mesas, A. E., Cavero-Redondo, I., Álvarez-Bueno, C., Sarriá Cabrera, M. A., Maffei de Andrade, S., Sequí-Dominguez, I., et al. (2020). Predictors of in-Hospital COVID-19 Mortality: A Comprehensive Systematic Review and Meta-Analysis Exploring Differences by Age, Sex and Health Conditions. PloS One 15 (11), e0241742. doi: 10.1371/journal.pone.0241742

Moutchia, J., Pokharel, P., Kerri, A., McGaw, K., Uchai, S., Nji, M., et al. (2020). Clinical Laboratory Parameters Associated With Severe or Critical Novel Coronavirus Disease 2019 (COVID-19): A Systematic Review and MetaAnalysis. PloS One 15 (10), e0239802. doi: 10.1371/journal.pone.0239802

Mudatsir, M., Fajar, J. K., Wulandari, L., Soegiarto, G., Ilmawan, M., Purnamasari, Y., et al. (2020). Predictors of COVID-19 Severity: A Systematic Review and Meta-Analysis. F1000Res 9, 1107. doi: 10.12688/f1000research.26186.2

Poly, T. N., Islam, M. M., Yang, H. C., Lin, M. C., Jian, W. S., Hsu, M. H., et al. (2021). Obesity and Mortality Among Patients Diagnosed With COVID-19: A Systematic Review and Meta-Analysis. Front. Med. 8, 620044. doi: 10.3389/ fmed.2021.620044

Shao, M., Li, X., Liu, F., Tian, T., Luo, J., and Yang, Y. (2020). Acute Kidney Injury Is Associated With Severe Infection and Fatality in Patients With COVID-19: A Systematic Review and Meta-Analysis of 40 Studies and 24,527 Patients. Pharmacol. Res. 161, 105107. doi: 10.1016/j.phrs.2020.105107

Shi, Z. L. (2021). Origins of SARS-Cov-2: Focusing on Science. Infect. Dis. Immun. 1 (1), 3-4. doi: 10.1097/ID9.0000000000000008

Shi, L., Lu, Z.-A., Que, J.-Y., Huang, X.-L., Lu, L., Ran, M.-S., et al. (2020). Prevalence of and Risk Factors Associated With Mental Health Symptoms Among the General Population in China During the Coronavirus Disease 2019 Pandemic. JAMA Netw. Open 3 (7), e2014053. doi: 10.1001/jamanetworkopen.2020.14053

Singh, D. P., Jamil, R. T., and Mahajan, K. (2020). "Nocturnal Cough," in Statpearls. Eds. M. Cascella, M. Rajnik, A. Cuomo, S. C. Dulebohn and R. S. Di Napoli (Treasure Island, FL: StatPearls Publishing).

Song, Z., Xu, Y., Bao, L., Zhang, L., Yu, P., Qu, Y., et al. (2019). From SARS to MERS, Thrusting Coronaviruses Into the Spotlight. Viruses 11 (1), 59. doi: 10.3390/v11010059

Tao, A., Zhenlu, Y., Hongyan, H., Chenao, Z., Chong, C., Wenzhi, L., et al. (2020). Correlation of Chest CT and RT-PCR Testing in Coronavirus Disease 2019 (COVID-19) in China: A Report of 1014 Cases. Radiology 296 (2), E32-E40. doi: 10.1148/radiol.2020200642

Undurraga, E. A., Chowell, G., and Mizumoto, K. (2021). COVID-19 Case Fatality Risk by Age and Gender in a High Testing Setting in Latin America: Chile, March-August 2020. Infect. Dis. Poverty 10, 11. doi: 10.1186/s40249-02000785-1
WHO (2021) WHO Coronavirus Disease (COVID-19) Dashboard. Updated on: 27 February 2021. Available at: https://covid19.who.int/ (Accessed on: July 15, 2021).

WHO News release (2021) WHO Calls for Further Studies, Data on Origin of SARSCov-2 Virus, Reiterates That All Hypotheses Remain Open. Available at: https:// www.who.int/news/item/30-03-2021-who-calls-for-further-studies-data-on-originof-sars-cov-2-virus-reiterates-that-all-hypotheses-remain-open.

Woo, P. C., Lau, S. K., Lam, C. S., Lau, C. C. Y., Tsang, A. K. L., Lau, J. H. N., et al. (2012). Discovery of Seven Novel Mammalian and Avian Coronaviruses in the Genus Deltacoronavirus Supports Bat Coronaviruses as the Gene Source of Alphacoronavirus and Betacoronavirus and Avian Coronaviruses as the Gene Source of Gammacoronavirus and Deltacoronavirus. J. Virol. 86, 3995-4008. doi: 10.1128/JVI.06540-11

Zhang, J. J. Y., Lee, K. S., Ang, L. W., Leo, Y. S., and Young, B. E. (2020). Risk Factors for Severe Disease and Efficacy of Treatment in Patients Infected With COVID-19: A Systematic Review, Meta-Analysis, and Meta-Regression Analysis. Clin. Infect. Dis. 71 (16), 2199-2206. doi: 10.1093/cid/ciaa576

Zhang, T., Wu, Q., and Zhang, Z. (2020). Probable Pangolin Origin of SARS-Cov2 Associated With the COVID-19 Outbreak. Curr. Biol. 30 (8), 1578. doi: 10.1016/j.cub.2020.03.063

Zhu, Z., Lian, X., Su, X., Wu, W., Marraro, G. A., and Zeng, Y. (2020). From SARS and MERS to COVID-19: A Brief Summary and Comparison of Severe Acute Respiratory Infections Caused by Three Highly Pathogenic Human Coronaviruses. Respir. Res. 21 (1), 224. doi: 10.1186/s12931-020-01479-w

Conflict of Interest: The authors declare that the research was conducted in the absence of any commercial or financial relationships that could be construed as a potential conflict of interest.

Publisher's Note: All claims expressed in this article are solely those of the authors and do not necessarily represent those of their affiliated organizations, or those of the publisher, the editors and the reviewers. Any product that may be evaluated in this article, or claim that may be made by its manufacturer, is not guaranteed or endorsed by the publisher.

Copyright (c) 2021 Sharma, Rajput, Bhatia, Arora and Sood. This is an open-access article distributed under the terms of the Creative Commons Attribution License (CC BY). The use, distribution or reproduction in other forums is permitted, provided the original author(s) and the copyright owner(s) are credited and that the original publication in this journal is cited, in accordance with accepted academic practice. No use, distribution or reproduction is permitted which does not comply with these terms. 